OECD Education Policy Perspectives No. 38

\title{
EDUCATION POLICY OUTLOOK IN BRAZIL
} WITH A FOCUS ON NATIONAL AND SUBNATIONAL POLICIES

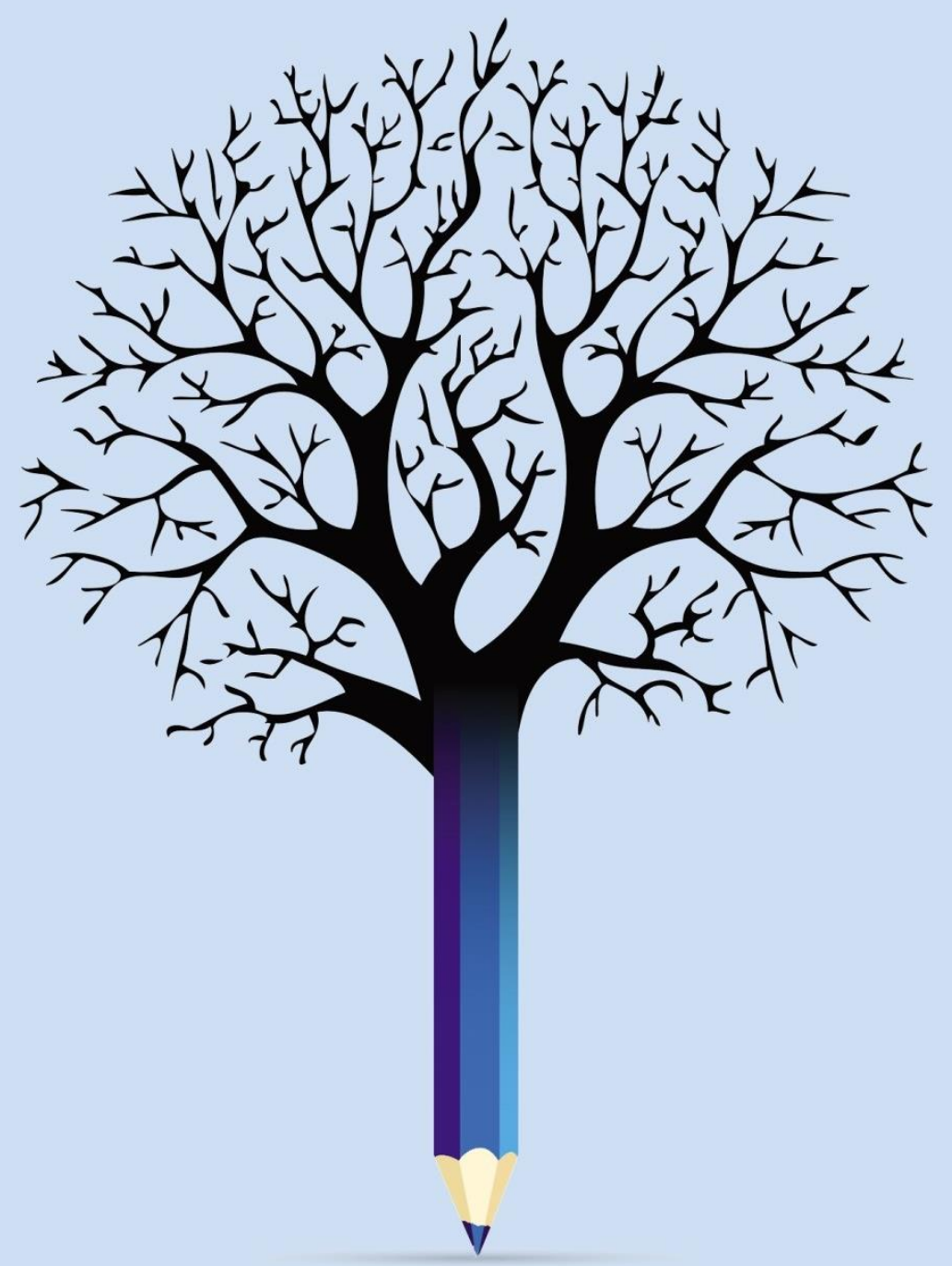




\section{Education Policy Outlook}

This policy profile on education in Brazil is part of the Education Policy Outlook series, which presents comparative analysis of education policies and reforms across OECD countries. Building on the OECD's substantial comparative and sectoral policy knowledge base, the series offers a comparative outlook on education policy. This country policy profile is an update of the first policy profile of Brazil $\left(2015_{[1]}\right)$ and provides: analysis of the educational context, strengths, challenges and policies; analysis of international trends; and insight into policies and reforms on selected topics in Brazil and other education systems. It is an opportunity to take stock of progress and where the education system stands today from the perspective of the OECD through synthetic, evidencebased and comparable analysis. This country policy profile has been prepared in two versions. Both offer an analysis of current strengths, challenges and policy priorities for Brazil, each with a respective focus on:

1. national and subnational policies, to analyse the evolution of ongoing and emerging related policy efforts in Brazil, including education responses to the COVID-19 pandemic.

2. international policies that may serve as possible inspiration to federal and subnational policy makers as they work to strengthen Brazil's education system.

Drawing on desk-based research of national and international evidence, as well as exploratory interviews with education policy stakeholders from across the system, these reports speak directly to Brazilian policy makers and implementation actors.

Designed for policy makers, analysts and practitioners who seek information and analysis of education policy that takes into account the importance of national context, the country policy profiles offer constructive analysis of education policy in a comparative format. Each profile reviews the current context and situation of a country's education system and examines its challenges and policy responses, according to six policy levers that support improvement:

- $\quad$ Students: How to raise outcomes for all in terms of 1) equity and quality and 2) preparing students for the future;

- Institutions: How to raise quality through 3) school improvement and 4) evaluation and assessment; and

- $\quad$ System: How the system is organised to deliver education policy in terms of 5) governance and 6) funding.

Country policy profiles also contain spotlight boxes on selected policy issues relating to the Education Policy Outlook's work on resilience and responsiveness, and which have particular relevance in the context of recovery from the COVID-19 pandemic. These aim to draw attention to specific policies that are promising or showing positive results and may be relevant for other countries.

In addition to the country-specific profiles, the Education Policy Outlook series includes a recurring publication offering comparative analysis of policy priorities, trends and evidence of progress or impact. Based on this analysis, as well as ongoing collaboration with over 40 education systems, the Education Policy Outlook began work to develop a Framework for Responsiveness and Resilience in education policy, to be launched in November 2021. As part of this work, Lessons for Education from COVID-19: A Policy Maker's Handbook for More Resilient Systems (2020[2]) was published to support countries in the context of an ongoing pandemic.

Special thanks to the Federal Government of Brazil and, in particular, the Brazilian Ministry of Education, for its active input during consultations and constructive feedback on this report, as well as other relevant actors from the Brazilian education system with whom the OECD Secretariat met as part of the preparation activities for this document. We also thank Itaú Social for its valuable financial support for the update of this country policy profile, in continuation of their support for the preparation of a first edition of this document for Brazil in 2015.

Authors: This country policy profile was prepared by Christa Rawkins, Diana Toledo Figueroa, Savannah Saunders and Thaiane Marques Pereira, as part of the work of the Policy Advice and Implementation Division, led by Paulo Santiago. Editorial support was provided by Stephen Flynn and Rachel Linden. This profile builds on the knowledge and expertise of many project teams across the OECD's Directorate for Education and Skills, to whom we are grateful. Manuela Fitzpatrick, Anna Vitória Perico e Santos, Caitlyn Guthrie and Elizabeth Fordham provided comments on behalf of the Global Relations Team.

Sources: Subject to country participation, this country policy profile draws on OECD indicators from the Programme for International Student Assessment (PISA), the Survey of Adult Skills (PIAAC), the Teaching and Learning International Survey (TALIS) and Education at a Glance, and refers to country and thematic studies such as OECD work on early childhood education and care, teachers, school leadership, evaluation and assessment for improving school outcomes, equity and quality in education, governing complex education systems, school resources, vocational education and training, and tertiary education. This profile also draws on information provided by Brazil between 2018 and 2021 as part of the Education Policy Outlook's activities with countries.

Annex B summarises key figures quoted in the different sections of this document.

More information is available from the OECD Directorate for Education and Skills (www.oecd.org/education/) and its web pages on the Education Policy Outlook (www.oecd.org/education/policy-outlook/). 


\section{Table of contents}

IN BRIEF

EQUITY AND QUALITY:

Brazil has increased participation in education, but multidimensional inequities persist

\section{PREPARING STUDENTS FOR THE FUTURE:}

Brazil has high returns to education but low completion rates hinder their fulfilment

\section{SCHOOL IMPROVEMENT:}

Students in Brazil view their teachers positively but educators could be more supported in their practice

\section{EVALUATION AND ASSESSMENT:}

Brazil has strong system-level evaluation, but room for more formative approaches in institutions

\section{GOVERNANCE:}

Brazil has a complex network of actors who could benefit from more clearly defined relationships

\section{FUNDING:}

Brazil has shown commitment to protecting education funding and redistributon, but inefficiencies reduce impact

ANNEX A:

Structure of Brazil's education system

ANNEX B:

Statistics

Figure 1. Trends in key educational outcomes

\section{Figures}

Figure 2. Equity and quality

Figure 3. Preparing students for the future

Figure 4. School improvement

Figure 5. Evaluation and assessment

Figure 6. Governance

Figure 7. Funding

\section{Spotlights}

Spotlight 1. Highlights of previous OECD reviews and recommendations for Brazil

Spotlight 2. Increasing flexibility and relevance through upper secondary reform (2017)

Spotlight 3. Strengthening the role of digital technology in education in Brazil 


\section{In Brief}

Figure 1. Trends in key educational outcomes

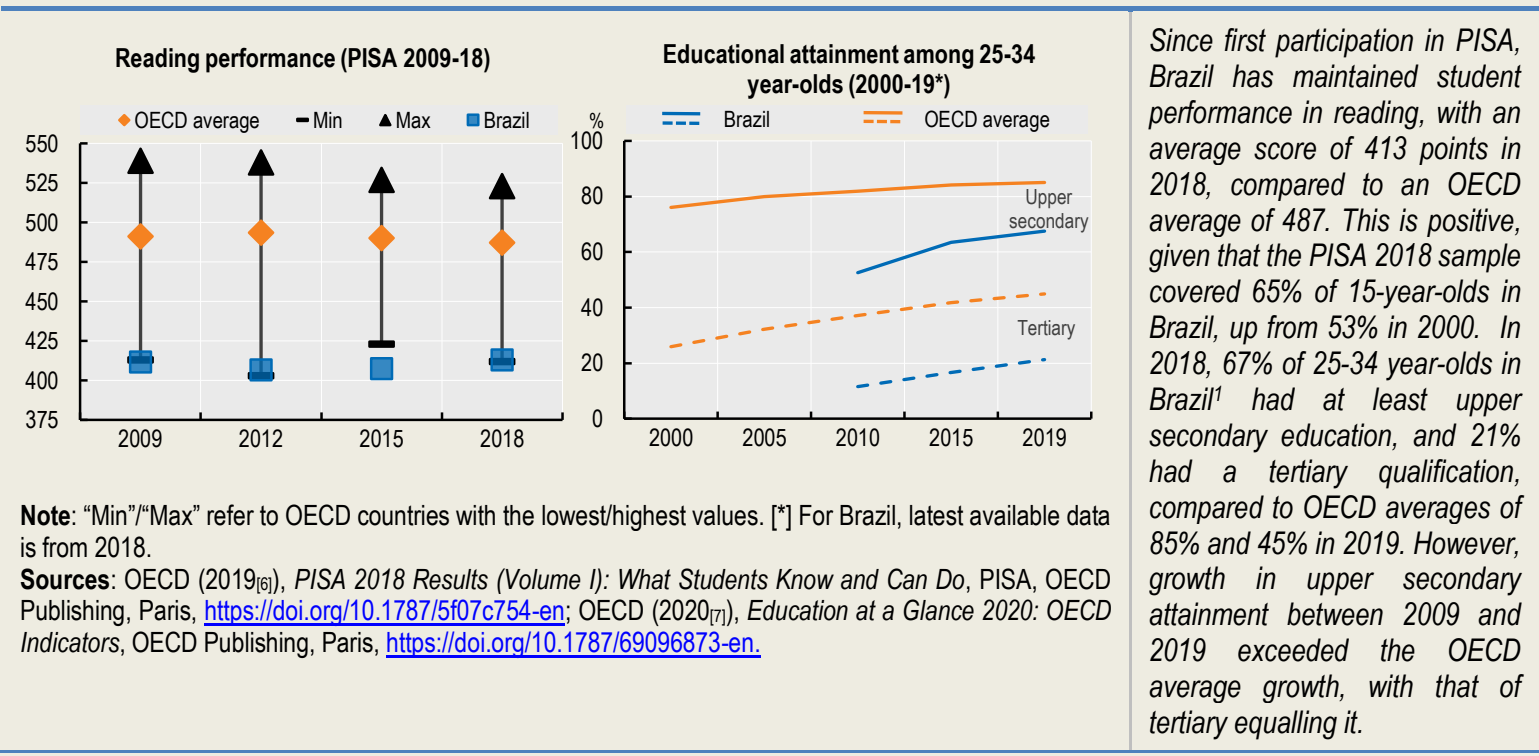

\section{Students}

- Brazil continues a long period of growth in educational participation and attainment since 2000 , with more recent progress in participation in early childhood education and care (ECEC) and higher education. For the latter, this has also benefitted disadvantaged students. In PISA, Brazil has also maintained performance in reading, with some improvements in mathematics and science while considerably increasing the number of students covered by the test.

- Several system-level practices have the potential to address ongoing equity challenges as students move through the system, including the extended duration of compulsory education and recent efforts to increase the flexibility of student pathways. The new National Common Curricular Base (Base Nacional Comum Curricular, BNCC, 2017/18) is also crucial in supporting equity through establishing universal minimum learning requirements regardless of background.

\section{Institutions}

- In Brazil, students view their teachers positively and perceive them to be enthusiastic; according to evidence from PISA, this is strongly related to higher student outcomes at school level in Brazil.

- Within a context of expansion of schooling, Brazil's teachers are qualified to a higher level than eight years ago, with most now holding a tertiary qualification. Recent initiatives aim to raise quality further, establishing national guidelines for initial teacher education (ITE), continuous professional development (CPD) and, currently under development, school leaders.

- Brazil has a well-renowned programme of system evaluation of student outcomes, which feeds into school improvement plans. Emerging national and subnational practices aim to strengthen evaluation in ECEC and vocational education and training (VET), and, in some cases, enhance improvement-focused career progression for teachers.

\section{System}

- Brazil's education system has a highly decentralised governance structure across the federal government, 26 states and 1 federal district2, and 5570 municipalities.

- In this context, collaboration and consultation are key: Brazil has several formal spaces for stakeholder engagement and there are promising emergent or small-scale initiatives for horizontal collaboration at federal and subnational level.

- A relatively high share of national wealth is dedicated to education. School funding is largely decentralised, but a commitment to redistributive mechanisms goes some way to reducing the inequalities this creates. 


\section{Selected indicators and key policy issues}

Figure 2. Equity and quality

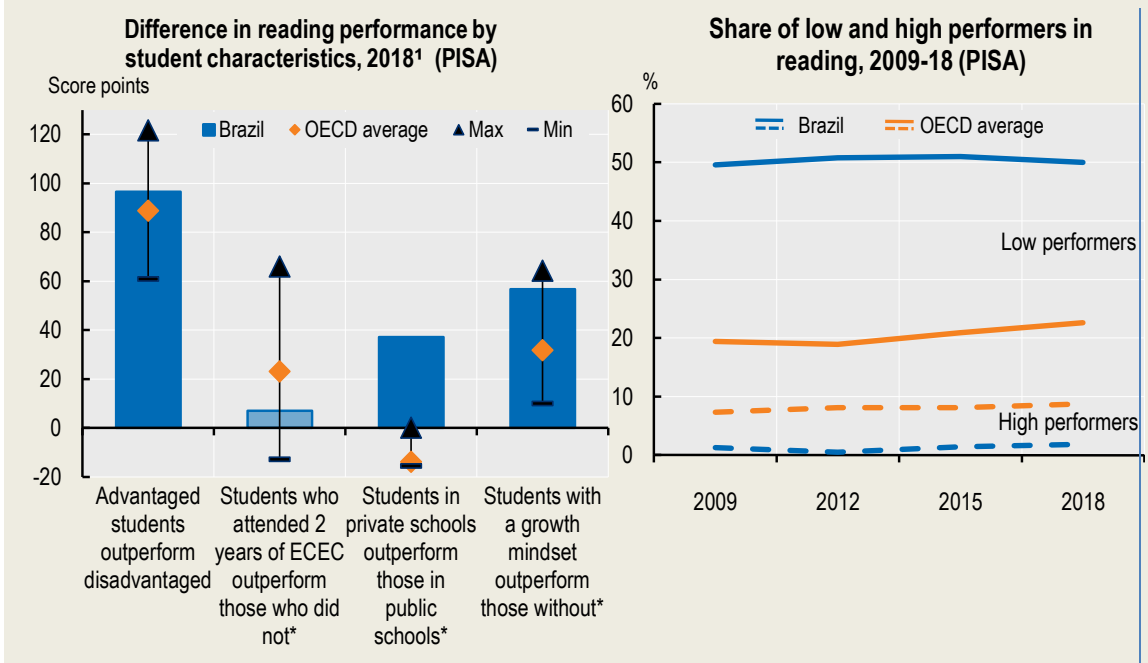

\section{Figure 3. Preparing students for the future}
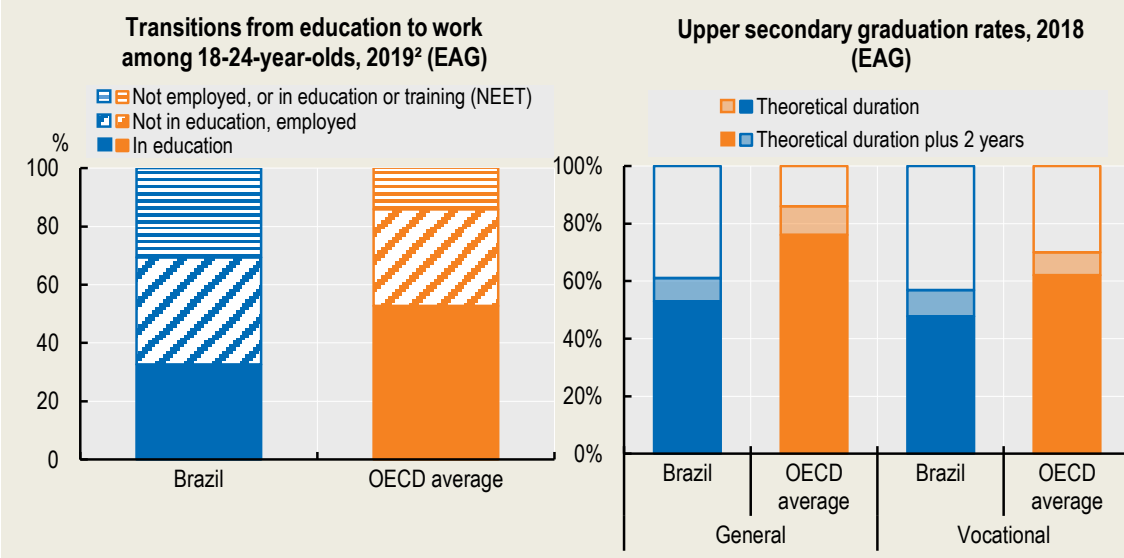

Figure 4. School improvement Students' perceptions of their learning environment, 2018 (PISA)
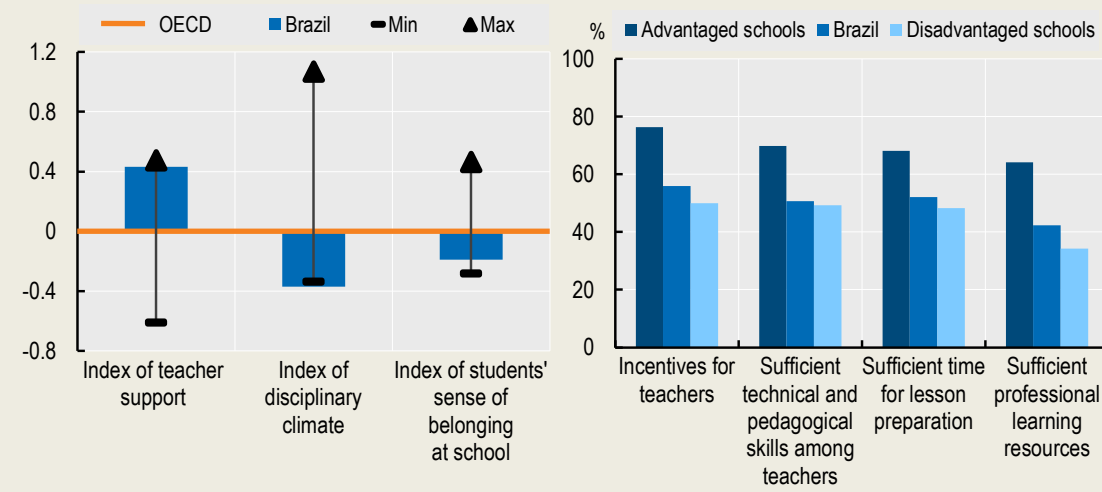

\section{Key policy issues}

Raising outcomes for all while addressing the inequities facing many. Multidimensional inequities related to parental education, geography and ethnicity, as well as socio-economic background, mean that universal approaches alone will not be enough. Brazil must implement holistic, individually responsive efforts for the most vulnerable. Brazil must also improve the quality of compulsory education: half of students in Brazil did not achieve minimum proficiency (PISA Level 2) in reading in 2018, while only $1.4 \%$ were high achievers (Level 5 or above), compared to OECD averages of $23 \%$ and $8.8 \%$.

Tackling low completion rates across the system. To reduce inefficiencies and realise the high returns that education in Brazil promises, raising completion rates and reducing drop-out is crucial. To this end, ensuring career guidance and support is available from a young age can help students make informed decisions about their future. Strengthening the alignment of skills supply and demand through nationwide and regional skills analysis and anticipation could also help improve student transitions into the labour market.

Empowering educators to drive improvement at institution level. This means enhancing school leaders' and teachers' professional skills, but also ensuring conducive working conditions, adequate decision-making powers at school level and improvement-focused accountability measures. Educators and other school-level actors should also be supported to better nurture more positive learning contexts for students to ensure that they do not miss out on valuable learning time. 
Figure 5. Evaluation and assessment

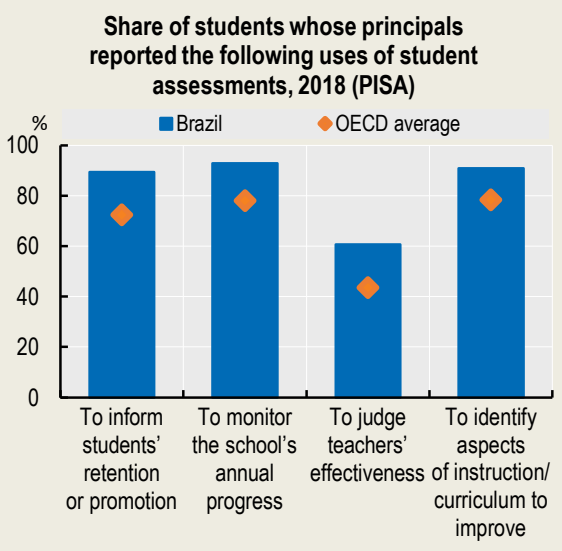

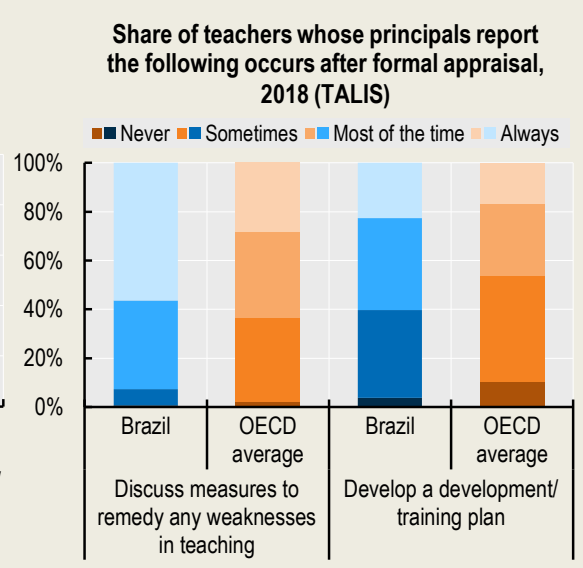

\section{Key policy issues}

Aligning student assessment at system and classroom level with large-scale reforms and short-term priorities. Brazil has undertaken wide efforts to strengthen evaluation infrastructure at school and tertiary levels. At institutional level, educators need support to engage more actively with monitoring and evaluation data for school and professional improvement, as well as with student formative assessment that drives classroom learning.

Enhancing policy processes to facilitate the implementation of recent ambitious reforms. Brazil is highly decentralised across federal government, states and municipalities. This makes it all the more necessary for Brazil to work on enhancing coherence and alignment across actors, as well as promoting vertical and horizontal collaboration structures that effectively support quality improvement. Quality assurance in distance education also matters.

\section{Figure 7. Funding}

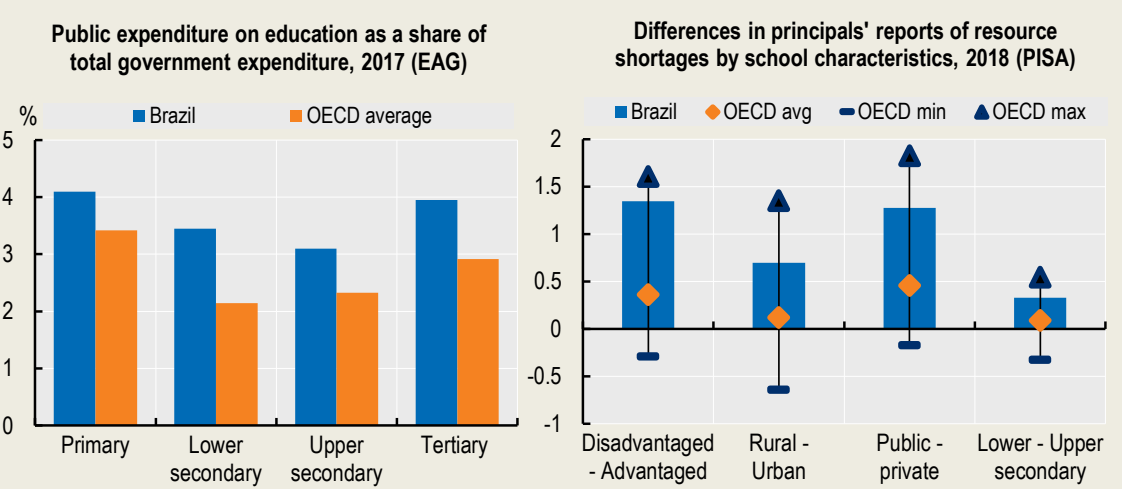

Reviewing funding priorities to ensure that public finances reach those who need it most and where returns are highest. To facilitate this, tying funding to outputs and outcomes could also reduce resource inefficiencies, prevalent across the system.

Notes: "Min"/“Max" refer to OECD countries with the lowest/highest values; [ $\left.{ }^{\star}\right]$ Score point difference after accounting for students' socio-economic status and language spoken at home; 1. Statistically significant values are shown in darker shades; 2. For Brazil, latest available data are from 2018.

Sources: OECD (2019[6] $)$, PISA 2018 Results (Volume I): What Students Know and Can Do, PISA, OECD Publishing, Paris, https://doi.org/10.1787/5f07c754-en; OECD (2019 $\left.{ }_{[8]}\right)$, PISA 2018 Results (Volume II): Where All Students Can Succeed, PISA, OECD Publishing, Paris, https://doi.org/10.1787/b5fd1b8f-en; OECD (2019/9), PISA 2018 Results (Volume III): What School Life Means for Students' Lives, PISA, OECD Publishing, Paris, https://doi.org/10.1787/acd78851-en; OECD (2020[10]), PISA 2018 Results (Volume V): Effective Policies, Successful Schools, PISA, OECD Publishing, Paris, https://doi.org/10.1787/ca768d40-en; OECD (2020[7]), Education at a Glance 2020: OECD Indicators, OECD Publishing, Paris, https://doi.org/10.1787/69096873-en; OECD (2020[11]), TALIS 2018 Results (Volume II): Teachers and School Leaders as Valued Professionals, TALIS, OECD Publishing, Paris, https://doi.org/10.1787/19cfo8df-en. 


\section{The Brazilian education system's response to the COVID-19 pandemic}

On 11 March 2020, the World Health Organisation declared the coronavirus (COVID-19) outbreak a global pandemic. Education systems across the world felt the force of the crisis as confinement measures triggered widespread closures of education institutions. In Brazil, although responses have varied according to state or municipality, schools and higher education institutions (HEls) generally closed from March 2020; as of April 2021, some were gradually reopening. In light of the work of the Education Policy Outlook in 2020 and 2021 in the context of this pandemic, this page offers insight into system responses across six key areas:

1. Ensuring continued access to learning and smooth educational pathways: In collaboration with MEC and in consultation with subnational actors, the National Council of Education (NCE) approved guidelines for distance education and recommendations about increasing flexibility in school calendars and curricular prioritisation. MEC, in partnership with subnational actors, released a guide for school reopening, including organisational, pedagogical and sanitary advice. Distance education in VET and adult learning was expanded through the New Pathways programme (see "Preparing Students for the Future"). For VET and higher education, the NCE recommended that practical training and assessments be carried out at a distance and the scope of national and subnational standardised assessments in general education be reduced. The National Examination of Upper Secondary Education was maintained but delayed with very high abstention rates. At subnational levels, most states and municipalities developed strategies to ensure pedagogical continuity: São Paulo's Education Media Centre produced and broadcast educational content via television, the internet and a mobile application with free access and data.

2. Understanding and strengthening the internal world of the student: Brazil successfully adapted the National School Feeding Programme, which assists all students in public schools. Federal government increased the Programme's budget and authorised all municipalities and states to utilise funds to distribute food kits directly to families. Guidelines to support these actions were also published. Different approaches were implemented. In Goiás, for example, a meal kit distribution programme aimed to mitigate school dropout: food deliveries were dependent on proof of class attendance and assignment completion. This helped reduce absence rates by $80 \%$.

3. Providing targeted support and interventions for quality learning: The NCE emphasised the importance of targeted supports, including adapting distance education resources for students with specific needs. MEC announced a programme to ensure access to mobile technologies for disadvantaged tertiary students without internet in the home, either through data top-ups or free packages. As a subnational example, Goiás' Electronic Equipment Reconditioning Programme donated refurbished computers and devices to schools and organisations for students without an internet connection.

4. Optimising wider engagement and collaboration beyond education institutions: MEC established an Emergency Committee with representatives from relevant federal bodies (see "Governance") and the subnational networks. Through the National Literacy Policy (see "Equity and Quality"), MEC supported families with young children through publishing guidance and pedagogical resources online, a literacy learning platform (GraphoGame) for 4-9 year-olds, and making courses for literacy teachers available to the general public. In Maranhão, state authorities collaborated with a nonprofit organisation, ECEC settings and municipal social assistance departments to distribute video, photo and audio content to families.

5. Empower education staff to lead richer learning processes across environments: Previously established platforms and training providers (see Spotlight 3), as well as new initiatives under the National Literacy Policy and New Pathways, helped deliver a wide range of distance training to teachers and VET trainers across the country.

6. Collecting, disseminating and improving the use of information about students: MEC launched a platform to monitor the evolution of the pandemic in federal institutions at tertiary level and in basic education. Some subnational authorities developed similar platforms. Santa Catarina's Programme for Decentralisation and Regionalisation of Actions to Combat COVID-19, provided a set of digital data analysis tools to support decision making at the municipal level; this included a colour-coded map of municipalities with instructions for schools based on level of health risk. São Paulo has been the first state to assess learning losses during the pandemic, administering standardised student assessments in Portuguese and Mathematics to a representative sample of students in the final years of primary, lower and upper secondary education. All groups showed losses, but these were particularly dramatic for the youngest and in mathematics.

\section{Strengthening adaptability and resilience in the context of COVID-19}

As Brazil works to balance short-term responsiveness with ongoing strategic aims, priorities emerge. These refer to striving for a more coherent response through a national strategy for learning recovery; supporting educators to develop new skills and knowledge to capitalise on new priorities and means of delivery; and addressing learning gaps with urgency to minimise disruption to students' educational journeys. Examples from international responses to the pandemic can help provide insight into possible ways forward [Read More]. 


\section{The Brazilian education system's response to the COVID-19 pandemic}

On 11 March 2020, the World Health Organisation declared the coronavirus (COVID-19) outbreak a global pandemic. Education systems across the world felt the force of the crisis as confinement measures triggered widespread closures of education institutions. In Brazil, although responses have varied according to state or municipality, schools and higher education institutions (HEls) generally closed from March 2020; as of April 2021, some were gradually reopening. In light of the work of the Education Policy Outlook in 2020 and 2021 in the context of this pandemic, this page offers insight into system responses across six key areas:

7. Ensuring continued access to learning and smooth educational pathways: In collaboration with MEC and in consultation with subnational actors, the National Council of Education (NCE) approved guidelines for distance education and recommendations about increasing flexibility in school calendars and curricular prioritisation. MEC, in partnership with subnational actors, released a guide for school reopening, including organisational, pedagogical and sanitary advice. Distance education in VET and adult learning was expanded through the New Pathways programme (see "Preparing Students for the Future"). For VET and higher education, the NCE recommended that practical training and assessments be carried out at a distance and the scope of national and subnational standardised assessments in general education be reduced. The National Examination of Upper Secondary Education was maintained but delayed with very high abstention rates. At subnational levels, most states and municipalities developed strategies to ensure pedagogical continuity: São Paulo's Education Media Centre produced and broadcast educational content via television, the internet and a mobile application with free access and data.

8. Understanding and strengthening the internal world of the student: Brazil successfully adapted the National School Feeding Programme, which assists all students in public schools. Federal government increased the Programme's budget and authorised all municipalities and states to utilise funds to distribute food kits directly to families. Guidelines to support these actions were also published. Different approaches were implemented. In Goiás, for example, a meal kit distribution programme aimed to mitigate school dropout: food deliveries were dependent on proof of class attendance and assignment completion. This helped reduce absence rates by $80 \%$.

9. Providing targeted support and interventions for quality learning: The NCE emphasised the importance of targeted supports, including adapting distance education resources for students with specific needs. MEC announced a programme to ensure access to mobile technologies for disadvantaged tertiary students without internet in the home, either through data top-ups or free packages. As a subnational example, Goiás' Electronic Equipment Reconditioning Programme donated refurbished computers and devices to schools and organisations for students without an internet connection.

10. Optimising wider engagement and collaboration beyond education institutions: MEC established an Emergency Committee with representatives from relevant federal bodies (see "Governance") and the subnational networks. Through the National Literacy Policy (see "Equity and Quality"), MEC supported families with young children through publishing guidance and pedagogical resources online, a literacy learning platform (GraphoGame) for 4-9 year-olds, and making courses for literacy teachers available to the general public. In Maranhão, state authorities collaborated with a nonprofit organisation, ECEC settings and municipal social assistance departments to distribute video, photo and audio content to families.

11. Empower education staff to lead richer learning processes across environments: Previously established platforms and training providers (see Spotlight 3), as well as new initiatives under the National Literacy Policy and New Pathways, helped deliver a wide range of distance training to teachers and VET trainers across the country.

12. Collecting, disseminating and improving the use of information about students: MEC launched a platform to monitor the evolution of the pandemic in federal institutions at tertiary level and in basic education. Some subnational authorities developed similar platforms. Santa Catarina's Programme for Decentralisation and Regionalisation of Actions to Combat COVID-19, provided a set of digital data analysis tools to support decision making at the municipal level; this included a colour-coded map of municipalities with instructions for schools based on level of health risk. São Paulo has been the first state to assess learning losses during the pandemic, administering standardised student assessments in Portuguese and Mathematics to a representative sample of students in the final years of primary, lower and upper secondary education. All groups showed losses, but these were particularly dramatic for the youngest and in mathematics.

\section{Strengthening adaptability and resilience in the context of COVID-19}

As Brazil works to balance short-term responsiveness with ongoing strategic aims, priorities emerge. These refer to striving for a more coherent response through a national strategy for learning recovery; supporting educators to develop new skills and knowledge to capitalise on new priorities and means of delivery; and addressing learning gaps with urgency to minimise disruption to students' educational journeys. Examples from international responses to the pandemic can help provide insight into possible ways forward [Read More]. 


\title{
Spotlight 1. Highlights of previous OECD reviews and recommendations for Brazil
}

\author{
Main national policies and practices included in \\ this country policy profile \\ Key challenges identified and recommendations \\ previously provided by the OECD
}

\section{STUDENTS}

- National Literacy Policy (Política Nacional de Alfabetização, 2019); Time to Learn (Tempo de Aprender, 2020); Tell Me (Conta Pra Mim, 2020)

- National Pact for Literacy at the Right Age (Pacto Nacional pela Alfabetização na Idade Certa, 2012-18)

- National Programme for Restructuring and Acquisition of Equipment for the Public School Network for ECEC (Proinfância, 2007); Kind Brazil (Brasil Carinhoso, 2012)

- National Plan for Early Childhood (Plano Nacional pela Primeira Infância, 2010-20, extended to 2030)

- Full-Time Upper Secondary programme (Ensino Médio Tempo Integral, EMTI, 2016); Full-Time Education (Educação Integral, 2008) in Pernambuco

- School Active Search Strategy (Busca Ativa Escolar, 2017)

- New Pathways (Novos Caminhos, 2019)

- National Catalogue of Technical Courses update (Catálogo Nacional de Cursos Técnicos, CNCT, 2020)

- New National Curriculum Guidelines for VET (Diretrizes Curriculares Nacionais Gerais para a Educação Profissional e Tecnológica, 2021)

- Quota Law (Lei de Cotas, 2012)

- Upper Secondary Reform (Novo Ensino Médio, NEM, 2017)

- Support Programme for NEM (Programa de Apoio ao Novo Ensino Médio, ProNem, 2018)

National Textbook Programme (Programa Nacional do Livro Didático, PNLD, 1985)
Key challenges identified [2014, 2015, 2018a, 2020a, 2020b]: The OECD has previously identified considerable disparities in education access and outcomes in Brazil across all levels, primarily due to students' socio-economic status and geographic location. The OECD has also noted that Brazil faces high rates of secondary school drop-out, which reflect a low level of core social and cognitive skills. The ongoing challenge of ensuring that all youth leave education with the skills required in the labour market had also been identified. Connected to this, the OECD reported challenges related to ensuring rigorous and systematic skills assessment and anticipation, measures for recognising prior learning and reducing the heterogeneity of training provision. Finally, the OECD noted that Brazil has faced high levels of unemployment for those age 18-24.

Summary of previous OECD recommendations: For ECEC, the OECD previously recommended that Brazil continue expanding access, prioritising disadvantaged families and regions. For older students, the OECD proposed increasing access to full-day schooling and making school more engaging and relevant by increasing subject choice. The OECD also recommended ensuring the early detection of students at risk of dropping out and providing individual, tailored support. Further recommendations have included strengthening links between schools and the labour market through expanding VET programmes and access to workbased learning, and enhancing employment services for young people. The OECD has also proposed better aligning training supply and university curricula with labour market demand using skill anticipation assessments and multi-stakeholder dialogue at local level, as well as facilitating formal and transparent certification of tertiary education and vocational training, particularly in online provision, and ensuring training subsidies adapt to the specific needs and context of the student and the local area. Finally, the OECD previously suggested that Brazil create a one-stop shop for youth to obtain information and advice about programmes and services available to them.

\section{INSTITUTIONS}

- New More Education Programme (Programa Novo Mais Educação, PNME, 2016; More Education Programme (Programa Mais Educação, 2007)

- National Curriculum Guidelines for ITE (BNC-Formação, 2019); National Curriculum Guidelines for CPD (BNCFormação Continuada, 2020).

- Institutional Programme for Teaching Initiation Scholarships (Programa Institucional de Bolsa de Iniciação à Docência, PIBID 2012); Residency Programme (Programa Residência Pedagógica, 2018)

- Modernisation of the Teacher Career (Modernização da Carreira Docente, 2019) in São Paulo

- Internal Commissions for the Prevention of Accidents and School Violence (Comissão Interna de Prevenção à Acidentes e Violência Escolar, CIPAVE, 2012) in Rio Grande do Sul
Key challenges identified [2014, 2017, 2018a, 2018b, 2020a, 2020b]: The OECD has previously identified challenges related to teacher quality, noting that recruits generally have low skill levels relative to other tertiary graduates in Brazil and that wages are comparatively low. Furthermore, the OECD noted that levels of on-the-job support and training are very heterogeneous across the country. At the same time, the OECD highlighted that school management is often low quality, partly as a result of political appointment practices. In higher education, the OECD identified challenges related to the design and implementation of national standardised assessments, as well as a need for greater transparency and rigour in institutional accreditation processes. In relation to student and adult VET, the OECD highlighted wide variation in training quality.

Summary of previous OECD recommendations: The OECD has previously recommended that Brazil improve the quality of education through ensuring that teaching is perceived as a 
- National Programme for Informatics in Education (Prolnfo, 1997-2007; Prolnfo Integrado, 2007-2017)

- Brazilian Digital Transformation Strategy 2018-21 (E-Digital)

- Connected Education Innovation Programme (Programa de Inovação Educação Conectada, PIEC, 2017)

- Media Education Centre of Amazonas (Centro de Mídias de Educação do Amazonas, CEMEAM, 2007) in Amazonas

- National Quality Parameters of Early Childhood Education (Parâmetros nacionais de qualidade da educação infantil, 2018); Quality Indicators in Early Childhood Education (2009)

- IDEB by School (2020); Click School (Clique Escolar, 2021)

- National School Health Survey (Pesquisa Nacional de Saúde do Escolar, PeNSE, 2009-15)

- Monitoring and Evaluation Plan of the VET offer (2020)

- Measuring Early Learning Quality and Outcomes (2018) in Boa Vista rewarding and high-status career attracting the most qualified graduates, including through enhancing remuneration, training and performance incentives. The OECD also suggested rewarding high-performing schools and better supporting low-performing schools to improve. More recently, the OECD suggested standardising curricula for teacher education to include more practical experience and introducing regular evaluation and support for novice teachers. It also recommended introducing temporary bonuses for qualified teachers to teach in difficult schools and better allocating teachers to schools according to skill needs across school types. For higher education, the OECD recommended improving the reliability and accessibility of information on higher education institutions' accreditation and outcomes. The OECD also recommended that Brazil improve higher education quality assurance by increasing the weight of outputs and outcomes in the institutional evaluation process and gathering feedback from a wider range of stakeholders. The OECD also proposed the introduction of systematic evaluations and certifications of vocational training programmes. In the area of digital education policy specifically, the OECD recommended more regular monitoring and evaluation based on pre-defined targets and indicators, and promoting information sharing on impactful initiatives.

\section{SYSTEM}

- National Education Plan (Plano Nacional de Educação, PNE 2014-24)

- National Common Curricular Base (Base Nacional Comum Curricular, BNCC, 2017)

- Legal Framework for Early Childhood (Marco Legal da Primeira Infância, 2016)

- Articulated Action Plans (Planos de Ações Articuladas, PARs, 2012)

- Education Development Arrangements (Arranjos de Desenvolvimento da Educação, ADEs, 2012)

- Support Programme for the Implementation of BNCC (Programa de Apoio à Implementação da BNCC, 2018)

- Direct Money to Schools Programme (Programa Dinheiro Direto na Escola, PDDE, 1995)

- New Fundeb (Novo Fundo de Manutenção e Desenvolvimento da Educação Básica e de Valorização dos Profissionais da Educação, 2020)

- Changes to Student Financing Fund (Fundo de Financiamento Estudantil, New FIES, 2018); ProUni (2004)

- Performance-based funding allocations in Ceará (2007)
Key challenges identified [2014, 2015, 2018b, 2020b]: The OECD previously noted the size and complex structure of education governance in Brazil as challenges to policy coherence, impact and implementation. In addition, a highly decentralised system together with large economic disparities has led to high variation in quality and outcomes. New national standards aim to address this, and the OECD has emphasised the need for federal and state governments to take the lead in co-ordinating implementation, noting that this has typically been weak leading to high spending inefficiencies, largely in secondary education. The OECD also noted that a disproportionate amount of spending goes to public tertiary provision.

Summary of previous OECD recommendations: The OECD previously recommended that Brazil review education funding, prioritising equity and cost-efficiency to increase focus on improving outcomes. In 2014, the OECD proposed increasing basic education spending through a higher Fundeb budget and gradually raising the share of national wealth spent on education towards the OECD average. More recently, in higher education, the OECD suggested that Brazil create an independent quality assurance agency, examining how this might support state and municipal systems. In relation to vocational and adult training, the OECD recommended that Brazil scale up resources for related policies, in particular for low-skilled, unemployed and informal workers, linking subsidies to outcomes. Finally, the OECD advised Brazil to introduce nationwide learning standards and curricula to improve adult basic education.

Note: The information on key challenges and recommendations in this Spotlight draws from a desk-based compilation from previous OECD publications (subject to country participation). The Spotlight is intended for exploratory purposes to promote policy dialogue, and should not be considered an evaluation of the country's progress on these recommendations. Causality should not be inferred either: while some actions taken by a country could correspond to previous OECD recommendations, the OECD acknowledges the value of internal and other external dynamics to promote change in education systems.

Main sources: OECD (2014[9]), Investing in Youth: Brazil, Investing in Youth, OECD Publishing, Paris, https://doi.org/10.1787/9789264208988en; OECD (2015 $[10])$, "Brazil Policy Brief: Developing Skills and Education for Growth", OECD Better Policies Series, OECD Publishing, Paris, https://www.oecd.org/policy-briefs/brazil-developing-skills-and-education-for-growth.pdf; OECD (2017[11]), Economic Policy Reforms 2017: Going for Growth, OECD Publishing, Paris, https://doi.org/10.1787/growth-2017-en; OECD (2018[12]), "Getting Skills Right: Brazil”, Getting Skills Right, OECD Publishing, Paris, https://doi.org/10.1787/9789264309838-en; OECD (2018[13]), "Rethinking Quality Assurance for Higher Education in Brazil", Reviews of National Policies for Education, OECD Publishing, Paris, https://doi.org/10.1787/9789264309050-en; OECD (2020[14]]), Going Digital in Brazil, OECD Reviews of Digital Transformation, OECD Publishing, Paris, https://doi.org/10.1787/e9bf7f8a-en; OECD (2020[15]), OECD Economic Surveys: Brazil 2020, OECD Publishing, Paris, https://doi.org/10.1787/250240ad-en. 


\section{EQUITY AND QUALITY: BRAZIL HAS INCREASED PARTICIPATION IN EDUCATION, BUT MULTIDIMENSIONAL INEQUITIES PERSIST}

Strengthening student performance for all emerged as a common policy priority across several OECD countries from 2014, with a particular focus on raising achievement among low performers (2018[16]). Analysis shows this is both a key challenge and a priority for Brazil. From 2000-18, Brazil expanded educational participation considerably while successfully maintaining stable reading performance and increasing mathematics performance in PISA by an average of 4.6 points every three years. In science, Brazil reduced the share of low performers by 5.6 percentage points from 2006 . Efforts to enhance performance must continue, however, as important challenges remain. In PISA 2018, 15-year-olds in Brazil performed well below the OECD average in reading (see Figure 1), mathematics (384 compared to 489) and science (404 compared to 489). In each, Brazil had a higher share of low achievers than many OECD countries: $23 \%$ of students achieved at least minimum proficiency (PISA Level 2) in reading, mathematics and science, compared to an OECD average of 64\% (see Figure 2). National data indicate that the share of students reaching grade-related minimum proficiency falls during upper secondary education, particularly in mathematics (2020[17]).

Early child hood education and care (ECEC) policies can increase the equity of education systems and raising access and quality were priorities for many education systems from 2008-17 (2018[16]). In Brazil, pre-school education (educação infantil - pré-escola), a two-year programme, generally begins at age four. Prior to this, children can attend daycare (educação infantil - crèche). Brazil has been working to increase ECEC enrolment, extending compulsory education to begin at 4 years old in 2009. By 2018, participation in pre-school was above the OECD average, at $90 \%$ of 4 -year-olds and $100 \%$ of 5 -year-olds. However, for younger children, participation is lower: in 2018 , only $65 \%$ of 3 -year-olds were enrolled in ECEC, compared to an average of $78 \%$. At the current rate of progress, Brazil will not meet the National Education Plan (Plano Nacional de Educação, PNE) goal of $50 \%$ enrolment for $0-3$ year-olds by $2024\left(2020_{[18]}\right)$. The 25 percentage point gap in participation rates between the lowest and highest socio-economic quintiles is a particular concern (2020[18]). PISA 2018 data indicate that in Brazil, as in other countries, ECEC can have an impact on later educational performance when children attend for two years. However, this impact was not as positive in Brazil as on average across the OECD. Alongside expanding participation, Brazil must therefore ensure quality.

According to OECD evidence, some system-level policies can favour equitable outcomes, such as a longer period of compulsory education, delayed tracking and limited ability grouping. Compulsory education in Brazil is from age 4 to 17, slightly longer than most OECD countries. Students are first tracked into different pathways at age 15, one year before the OECD's most common age. Grade repetition appears to be a relatively frequent practice in Brazil: in 2018, 34\% of 15-year-olds reported having repeated a grade, compared to $11 \%$ on average, with considerably higher rates among disadvantaged students. Evidence suggests that key transition years (Years 3 and 6 , and Grade $\left.1^{3}\right)$ have the highest concentration of repeaters $\left(2018_{[19]}\right)$. However, in Brazil, as in other countries, grade repetition does not lead to higher outcomes; in Brazil it also contributes to a high rate of age-grade distortion which can exacerbate drop-out rates $\left(2018_{[20]}\right)$. Among many education systems across the OECD, preventing grade repetition was identified as an emerging policy priority in 2018 as its costliness and inefficiency are increasingly recognised $\left(2018_{[16]}\right)$. Brazil also experiences informal school segregation with an above-average isolation index for high-achieving students (0.30 compared to 0.21$)$ and the socio-economically advantaged $(0.33$ compared to 0.19 ), despite only a small share of schools using academic selection. Private schools may contribute to this: advantaged students are more likely to attend private school, where, even after accounting for socioeconomic status, students scored 37 points higher in reading in PISA 2018. There is evidence that the COVID-19 pandemic may have reduced participation in private schooling $\left(2021_{[21]}\right)$. Nevertheless the quality of public schools in Brazil must increase to mitigate the inequities resulting from the existence of socially-exclusive private schools.

Brazilian education faces multidimensional equity concerns requiring holistic responses that consider long-standing socio-economic, geographic and ethnic disadvantage. Socio-economic disadvantage is a key driver of low performance in Brazil, explaining 14\% of the variance in reading scores in PISA 2018 compared to $12 \%$ on average across the OECD. Advantaged students outperformed their disadvantaged peers by 97 points in reading in Brazil, compared to an average gap of 89 points. Intergenerational trends in Brazil also show that two-thirds of children of parents without basic education do not attain it themselves $\left(2020_{[15]}\right)$. Geography plays a role: in the more rural North and Midwest, ECEC enrolment was well below the national average in 2018 (2019[22]) while across many PNE goals, the North and Northeast lag in education coverage and quality $(2020[18])$. Black and mixed children generally form the majority of those in poverty and are more prone to an accumulation of social and educational deprivations (2018[20]).

Prolonged school closures during COVID-19 are likely to have exacerbated these inequities: around $30 \%$ of disadvantaged students in Brazil, as well as those in rural schools, reported having access to a computer at home for school work in 2018 , compared to nearly $90 \%$ for advantaged students or those in private schools. Across the OECD, policy work to address inequities has typically focused on prioritising specific groups for targeted supports or resources $\left(2018_{[16]}\right)$. While this remains important, there is also growing international momentum for individually responsive efforts and holistic approaches that consider the multiple vulnerabilities interacting to diminish opportunities and outcomes for some children (2020[2]). In Brazil, both approaches will be critical in the COVID-19 recovery and beyond. 


\section{Where does Brazil stand on education equity and quality?}

\section{Key strengths}

- Brazil has greatly expanded participation in education, particularly in ECEC, while maintaining, and in some cases improving, performance.

- The long duration of compulsory education may foster greater equity as younger students move through the system.

\section{Key challenges}

- Increasing the share of students achieving minimum proficiency in the core PISA disciplines.

- Enhancing the quality of ECEC and equity of access to increase the positive impact on future outcomes.

- Analysing the intersectionality of inequities to design supports for those with multiple vulnerabilities.

\section{Building on policy efforts in Brazil to move forward}

By defining the skills that all students should acquire regardless of background or school, Brazil's National Common Curricular Base (Base Nacional Comum Curricular, BNCC, 2017/18) is a crucial step in promoting equity and quality. Ensuring successful implementation despite the challenges posed by the pandemic must now be a priority (see Spotlight 4).

The National Literacy Policy (Politica Nacional de Alfabetização, PNA) $\left(2019_{[23]}\right)$, aims to raise literacy skills for all, focusing on the youngest. Several initiatives support implementation. Time to Learn (2020[24) (Tempo de Aprender) works to raise the quality of literacy teaching and learning across four pillars: professional development; pedagogical supports; literacy assessments; and valuing literacy professionals, through performance-related financial rewards. Implementation of the latter has been delayed due to school closures in 2020. Currently, over $80 \%$ of municipalities have joined the programme. Tell me (2020 [25) (Conta Pra Mim) aims to strengthen home-based literacy learning with online materials and targeted in-person training for families. MEC is also partnering with the Ministry of Citizenship's Happy Childhood initiative (Criança Feliz) to offer home visits for child development (2020[26). . Brazil's engagement with families and relevant community actors aligns with international policy trends to reduce low performance in core subjects $\left(2018_{[16])}\right.$. As evidenced internationally during the COVID-19 pandemic, such partnerships are also critical in enhancing resilience and responsiveness by ensuring continuity of support in unstable contexts (forthcoming[27]). At the same time, as some planned measures within the PNA may divert from previous initiatives, alignment efforts will be important to reduce disruption (2020[28) [Read More]. Implementation should also learn from the challenges faced by the PNA's predecessor the National Pact for Literacy at the Right Age (Pacto Nacional pela Alfabetização na Idade Certa, 2012-18) (2019929), by ensuring that training adequately connects theory with practice and that subnational authorities and educators can adapt initiatives to their contexts.

The National Programme for Restructuring and Acquisition of Equipment for the Public School Network for ECEC (Proinfância, 2007) and Kind Brazil (Brasil Carinhoso, 2012) supported the expansion of ECEC. While Proinfância provided infrastructural assistance to municipalities, standardising construction to enhance efficiency, Kind Brazil took a holistic view of child development, funding municipal-level income-, health- and food-related measures for the most disadvantaged families. Proinfância has benefitted areas with low provision, but there are some non-completed projects $\left(2019_{[30]}\right)$ and calls to strengthen technical support for pedagogical aspects $\left(2017_{[31]}\right)$. Kind Brazil, now discontinued, helped lift 8.1 million children out of extreme poverty by $2014\left(2016_{[32]}\right)$. More recent efforts have the potential to build on the holistic approach by promoting inter-sectoral action (see "Governance"). To enhance quality, in 2020, Brazil updated and extended the National Plan for Early Childhood (Plano Nacional pela Primeira Infância, 2010) to $2030\left(2020_{[33]}\right)$. The plan defines 26 guiding principles for early education, including the integration of education and care, a focus on play, and collaboration with families. Planned actions include improving Proinfância, enhancing staff skills and careers, embedding the BNCC, and strengthening monitoring. Translating this into action at municipal level is now the challenge. Internationally, policies aiming to enhance ECEC quality have focused on modifying or clarifying what and how children are expected to learn. The BNCC can support this. MEC's recent commitment to monitor and evaluate BNCC implementation (see Spotlight 4) will be thus a useful source of evidence to inform a clear implementation strategy for the National Plan.

The Full-Time Upper Secondary programme (Ensino Médio Tempo Integral, EMTI, 2016), provides federal funding to support states to move from an average school day of four hours to seven. Funding covers operational and pedagogical activities and resources. By 2019, expansion of full-time schooling was fastest at upper secondary level, but, at 13.9\%, the share of public schools offering full-time upper secondary was well below the PNE goal of $50 \%$ by 2024 (2020[18]). EMTI was inspired by Pernambuco's Full-Time Education policy (Educação Integral, 2008), credited with dramatically improving outcomes and enhancing efficiency by reducing age-grade distortion $(2020$ [34). EMTI could thus benefit from replicating some of the identified success factors of this policy, including continuity over multiple government mandates and evidence-informed adjustment (2020[34]). In 2021, MEC released new guidelines for EMTlhttp://www.in.gov.br/en/web/doul-/portaria-n-2.116-de-6-de-dezembro-de-2019$232132483\left(2019_{[35)}\right)$ lowering some of the pre-requisites and implementation benchmarks. While this will help expand the number of participating schools, Brazil must ensure changes do not lower the quality of outcomes. 


\section{PREPARING STUDENTS FOR THE FUTURE: BRAZIL HAS HIGH RETURNS TO EDUCATION BUT LOW COMPLETION RATES HINDER THEIR FULFILMENT}

The capacity of a country to effectively develop skills and labour market perspectives can play an important role in the educational decisions of the population. In 2018, $14 \%$ of $25-64$ year-olds in Brazil had not completed primary education, and $47 \%$ had not completed upper secondary, compared to OECD averages of $2 \%$ and $22 \%$ in 2019. This is changing in Brazil: the share of 25-34 year-olds with less than upper secondary education in 2018 was half that of 55-64 year-olds. Educational attainment is increasingly influential in Brazil: those without upper secondary education, for example, were more vulnerable to declining employment rates from 2015. In 2018, 31\% of 18-24 year-olds in Brazil were not employed nor in education or training (NEET), more than twice the OECD average of $14 \%$ in 2019 (see Figure 3). The COVID-19 pandemic is likely to exacerbate this: Brazil's overall unemployment is projected to grow from $12 \%$ in 2019 to $15 \%$ in $2022\left(2020_{[15]}\right)$. Such challenges are not unique to Brazil; from 2008-17, many education systems identified improving transitions to work and reducing NEET rates as policy priorities $\left(2018_{[16])}\right.$.

Upper secondary education (ensino médio) is compulsory in Brazil and takes place in either general or technical institutions, usually over three years. Upon completion, students receive a diploma enabling access to higher education. Despite growing student participation and attainment at this level, performance is often low (see "Equity and Quality") and drop-out rates are high. In 2018, only 53\% of students graduated after 3 years (theoretical duration), increasing to just $61 \%$ after 5 years, by which point most of those who had not completed the programme were no longer enrolled. Drop-out rates among students in the lowest income quintile are eight times higher than for those in the highest $\left(2020_{[15]}\right)$. Reducing early school leaving was identified as a policy priority for several OECD education systems from 2008-17 (2018[16]); by enhancing flexibility and transparency around what students are able to learn in upper secondary, current reforms in Brazil align with some common international responses (see Spotlight 2).

Vocational education and training (VET) can ease entry into the labour market, yet many VET programmes across the OECD make insufficient use of workplace training. VET has been an area of policy focus for many education systems, with increasing attractiveness and employer engagement as commonly identified priorities $\left(2018_{[16]}\right)$. In Brazil, upper secondary VET (Educação Profissional e Técnica) can be integrated (general and technical courses at the same institution), concomitant (separate institutions) or, most commonly, sequential (on completion of general education). In PISA 2018, VET students in Brazil outperformed their peers in general programmes by 39 score points in reading, after accounting for socio-economic status, reversing the OECD trend. Research suggests that Brazil's model, which combines general and technical curricula, strengthens learning through greater focus on application $\left(2020_{[36]}\right)$; however, the use of admissions tests for many VET schools is also a contributing factor. VET enrolment in Brazil is low, though: only $11 \%$ of upper secondary students in 2018 were in vocational programmes, well below the OECD average of $42 \%$ and the PNE target of $25 \%$ by 2024 . Completion rates are also low: in 2018, only 58\% of upper secondary VET students had graduated by 2 years after the theoretical duration (see Figure 3). Current reforms target the integrated model, which has lower drop-out rates, and aim to increase participation (2018[37]) (see Spotlight 2).

Ensuring equal access to higher education and improving quality, already identified as common policy priorities across many OECD countries $\left(2018_{[16]}\right)$, are also relevant for Brazil. Higher education mostly takes place in universities in Brazil, but also in federal institutes, university centres or colleges. Most students are enrolled in 4-5 year Bachelor's programmes but postgraduate qualifications, including professional Master's, are increasingly popular. Entry is typically based on students' results in the optional National Examination of Upper Secondary (Exame Nacional do Ensino Médio, ENEM), although alternative or additional criteria may apply. Entry to public HEls, which do not charge tuition fees and are often higher performing, is more competitive. As such, educational inequities that accumulate across compulsory schooling can negatively impact access to quality, affordable tertiary education. Yet growth in tertiary attainment has benefitted disadvantaged and non-white students too (see "Recent policies and practices"). It also produces high returns: in 2018, tertiary-educated 25-34 year-olds were employed at a rate 11 percentage points higher than their peers with upper secondary attainment, with a wage premium of $144 \%$, compared to OECD averages of 9 percentage points and 54\%. Perhaps as a result, in PISA 2018, $75 \%$ of Brazil's 15 -year-olds reported expecting to complete higher education, including $68 \%$ of those without minimum proficiency in core PISA subjects. This mismatch may ultimately contribute to high non-completion rates: only one-third of Bachelor's students in Brazil graduated within the theoretical duration in 2017. Timely career guidance can help students recognise the benefits of education and develop realistic expectations but, in PISA 2018, around onequarter of Brazil's 15-year-olds attended schools without guidance. International evidence offers interesting approaches that could help Brazil strengthen career guidance and develop nationwide skills anticipation and graduate tracking systems $\left(2020_{[15]}\right)$ [Read More].

Adult education in Brazil is critical in addressing low attainment. Education for Youth and Adults (Educação de Jovens e Adultos, EJA) offers 6-month modules to people aged over 15 returning to formal education; short training courses (Cursos FIC) offer professional qualifications. The OECD noted that, despite relatively high enrolment, EJA is rarely tailored to adults' needs, resulting in low completion $\left(2020_{[15]}\right)$ while FIC courses are very heterogeneous in quality and availability $\left(2018_{[12]}\right)$. High drop-out rates across the education system mean that individual and societal investments do not consistently result in expected economic and social returns, inhibiting efficiency and resilience. 


\section{Where does Brazil stand on preparing students for the future?}

\section{Key strengths}

- Labour market and financial returns to education are high.

- Participation and attainment levels in vocational and general education are growing, including for disadvantaged students at tertiary level.

\section{Key challenges}

- Reducing drop-out and non-completion rates across different programmes and education levels.

- Increasing participation and quality across the VET offer.

- Strengthening the alignment of skills supply and demand through tailored, evidence-based provision and guidance.

\section{Policy efforts in Brazil to move forward}

In response to persistently high numbers of out-of-school children, the School Active Search strategy (Busca Ativa Escolar) $\left(2017_{[38]}\right)$ relies on municipal-level inter-sectoral collaboration, with state support, to identify, enrol and monitor disengaged students through a free digital platform and phone application. Developed by UNICEF Brazil, in collaboration with national bodies of municipal directors for education, health and social assistance, it was piloted in 2015. From 2017, MEC funded a network of agents to support national implementation. By July 2020, over 3160 municipalities had adopted the strategy, with over 60000 students (re)enrolled (n.d.[39]). During COVID-19, guidelines were adapted and the platform continued to be a useful real-time tool to track students. It will also be important as schools reopen: international evidence suggests that school closures increase the chance of students disengaging from their learning and their peers $\left(2020_{[2]}\right)$. A key strength of School Active Search is its facilitation of collaboration through digital tools. However, international experience shows that while tracking matters, early identification of at-risk students and relevant intervention, including individualised supports and orientation, can provide even higher payoff (2018[16]) [Read More].

New Pathways (Novos Caminhos, 2019), MEC's strategic agenda for VET (2020[40]), appears to follow international trends in policy responses to VET-related priorities. New Pathways aims to enhance upper secondary, post-secondary and tertiary VET in line with labour market demand and technological innovation, and to increase enrolment by $80 \%$ by 2023 . There are three key actions: 1) strengthen planning, management and governance through evidence-based decision making, regulation and consistency; 2) improve co-ordination with subnational actors, particularly to implement the upper secondary reform and expand the offer; 3) strengthen links between education, employment and local development by promoting innovation and entrepreneurialism. It is also taking advantage of digital learning both to strengthen teaching and training and expand the VET offer (see Spotlight 3). New Pathways aims to overcome some of the identified weaknesses of previous efforts in the sector, such as PRONATEC (2011), including high drop-out rates due to a lack of alignment with local labour market needs, and a focus on enrolment over quality $(2018[37])$. Stronger monitoring and evaluation, regional skills anticipation and targeted resourcing are therefore key (2020[15]).

As part of these efforts, Brazil updated the National Catalogue of Technical Courses (Catálogo Nacional de Cursos Técnicos), which provides all stakeholders with information about professional profiles, fields, and qualification, certification and pathway options, aiming to make the training offer more consistent and transparent. This is important: international policy experiences in VET indicate that raising awareness of new and enhanced opportunities is an ongoing challenge (2018[16]). Updates began in 2018 with wide stakeholder engagement; by the end of 2020 , a fully digital version was launched $\left(2021_{[41]}\right)$. The OECD commended the engagement with the private sector (2020[14]); however, previous recommendations to develop regional catalogues informed by tighter skills anticipation analyses have not yet been implemented $\left(2018_{[12]}\right)$. MEC has analysed and mapped state demand for VET to inform federal subsidies. State-specific reports consider current course supply, future demand, and COVID-related challenges and opportunities. Other efforts to enhance VET quality include quality assurance measures (see "Evaluation and Assessment") and new integrated National Curriculum Guidelines for VET (2021[42]). These and other planned initiatives are promising; at the same time, the disparate and diverse nature of VET in Brazil, and the ongoing economic disruption of the COVID-19 pandemic, complicate implementation. Strong steering from federal government, as well as transparent monitoring and efforts to engage stakeholders are required. Federal and state actors could draw lessons from states with strong VET systems (see Spotlight 2).

Brazil's Quota Law (Lei das Cotas, 2012) is an affirmative action policy reserving 50\% of places in public universities for students from public schools, including $25 \%$ from families earning equal to or less than the minimum wage. The share of black, mixed, and indigenous students must also mirror broader society. From 2011-16, the share of black and mixed students enrolled rose from $11 \%$ to $30 \%\left(2019_{[43]}\right)$. Other related policy efforts aim to make private HEls more affordable (see "Funding"). While quotas and financial supports have raised diversity and should be maintained, they do not tackle the root cause of inequity at this level. Competitive admissions for public HEls favour advantaged students, often in private or higher-performing schools or able to afford private tutoring. Disadvantaged students are thus more likely to have to pay to attend private HEls, which tend to have lower outcomes and prestige (see "Governance"). Therefore, policy efforts to enhance access to public tertiary must be complemented with efforts to enhance quality, particularly in the private sector. This is an identified policy trend across many OECD countries where such efforts have focused on tertiary education frameworks or strategies, labour market relevance and internationalisation $\left(2018_{[16]}\right)$. 


\section{Spotlight 2. Increasing flexibility and relevance through upper secondary reform (2017)}

In 2017, Brazil approved a major New Upper Secondary reform (Novo Ensino Médio, NEM) aiming to enhance quality and raise student engagement. In doing so, Brazil hopes to strengthen the relevance of upper secondary to labour market needs and student interests and increase completion rates. International policy trends in this area have focused on developing more engaging and relevant pathways, advancing student guidance and updating curricula. Brazil's reform follows this direction with changes in three key areas:

- Curricular flexibility: At the heart of the reform is the introduction of the BNCC (see Spotlight 4). To modernise the course offer, previously seen as overloaded and examination-focused, NEM promotes flexible learning pathways, reducing the mandatory component from 13 to 3 subjects - Portuguese, mathematics and English. This and other areas of knowledge established by the BNCC must cover $60 \%$ of instruction time, up to $20 \%$ of which can occur online. For the remaining $40 \%$, students choose from five pathways - languages and their technologies, mathematics and its technologies, natural sciences and their technologies, applied human and social sciences, and VET. At the school's discretion, and according to availability, students may choose to study a full pathway, mandatory units from a selected pathway and supplementary units from one other, or units from multiple pathways.

- Full-time schooling: Through NEM, Brazil aims to universalise full-time schooling at this level, moving from, typically, 800 hours per year in 2018, to at least 1000 hours in 2022 and eventually 1400 hours. Efforts build on subnational and national initiatives already underway (see "Equity and Quality").

- Future relevance: NEM encourages all schools to offer curricular units focused on developing students' "life projects". This includes supporting students to develop transversal skills to support employment, and offering education and careers guidance. Brazil aims to strengthen all students' exposure to VET, too. All schools must offer at least one VET pathway; students in non-VET pathways may study VET modules. Brazil also aims to increase the quality of upper secondary VET through better balancing practical and academic learning, enhancing collaboration with the private sector and promoting intermediate qualifications.

Implementation of NEM is the responsibility of state administrations, but federal leadership is essential in guiding action and consistency. In 2018, MEC established the Support Programme for NEM (Programa de Apoio ao Novo Ensino Médio, ProNem) to offer technical and financial assistance to states for implementation planning, piloting and professional development for educators and school leaders. With MEC's guidance, states were expected to elaborate implementation plans, identify and recruit pilot schools (2019), then proceed to full implementation (2020). The federal government has also committed to 10 -year funding streams to schools implementing the reform, based annually on student numbers, through the Direct Money to Schools Programme (Programa Dinheiro Direto na Escola, PDDE). The World Bank provides further financial support, with a focus on equitable implementation. To oversee implementation, MEC established a monitoring committee with national and subnational representatives; states are expected to do the same.

By the end of 2020, all states had schools participating in pilot projects, with eight moving to full implementation from 2021; implementation plans for all but two states had been finalised. Through New Pathways (see "Preparing Students for the Future"), Brazil considerably expanded the training offer for VET teachers and trainers - taking advantage of digital training solutions (see Spotlight 3) held a webinar series for state actors to discuss the implementation of VET pathways, and undertook state-level analysis to identify potential roadblocks. MEC has also now included VET in the National Textbook Programme (Programa Nacional do Livro Didático, PNLD). However, there are ongoing challenges: for state-level and institutional actors. The interdependency of NEM and BNCC complicates implementation, and the slower pace of curricular adaptation at upper secondary level (see Spotlight 4) is also impeding the implementation of NEM. The World Bank notes an absence of state-level monitoring and evaluation, and no state-level specific planning for vulnerable communities. This is a concern as less well-resourced schools and networks may struggle to ensure a wide course offer.

Furthermore, monitoring indicators suggest that MEC will measure flexibility based on schools offering at least two pathways only this risks creating a false sense of choice. In a survey of state-level actors, reported implementation obstacles include states' technical capacity and resources, as well as continued ambiguity regarding the alignment of ENEM for which the reference matrix has not yet been updated and there is a perceived lack of dialogue. Going forward, facilitating the delivery of ProNEM support and increasing transparency around ENEM adaptations should be priorities for federal government. Brazil can also turn the heterogeneity of implementation progress to its advantage, promoting peer learning and collaboration between states and institutions; such approaches have worked well in international examples [Read More]. The state of Paraiba, for example, which has a high level of full-time schooling and a well-developed VET offer, has a lot of knowledge and experience to share with states for whom developing VET pathways will be a challenge (2021 [44]).

Sources: Instituto Unibanco (2020[45]) Análise dos processos de implementação do Novo Ensino Médio em Estados Brasileiros: Ficha Técnica [Analysis of the implementation processes of the New High School in Brazilian States: Technical File], Instituto Unibanco, São Paulo; MEC (2018[46]), Portaria $N^{0}$ 649, de 10 de julho de 2018 [Ordinance No. 649 of 10 July 2018], https://www.in.gov.br/materia/lasset_publisher/Kujrw0TZC2Mb/content/id/29495231/d01-2018-07-11-portaria-n-649-de-10-de-julho-de-2018-29495216 (accessed 19 February 2021); MEC/CONSED (2018), Guia de Implementação do Novo Ensino Médio, [Implementation Guide for New Upper Secondary], https://observatoriodeeducacao.institutounibanco.org.br/cedoc/detalhe/guia-de-implementacao-do-novo-ensino-medio,41cefaab-dbf8-49e2-

ab92-1779a945fb00 (accessed 19 February 2021); Presidência da República (2017[47]), Lei No 13.415, de 16 de feveiro de 2017 [Law No. 13.415 of 16 February 2017], http://www.planalto.gov.br/ccivil_03/_ato2015-2018/2017/lei//13415.htm (accessed 19 February 2021); World Bank $\left(2020_{[48]}\right)$, Support to Upper Secondary Reform Operation", Projects and Operations, webpage, https://projects.worldbank.org/en/projectsoperations/project-detail/P163868 [accessed 19 February 2021]. 


\section{SCHOOL IMPROVEMENT: STUDENTS IN BRAZIL VIEW THEIR TEACHERS POSITIVELY BUT EDUCATORS COULD BE MORE SUPPORTED IN THEIR PRACTICE}

Developing positive learning environments for students that enable school leaders and teachers to succeed is essential in raising achievement. Students in Brazil view their teachers positively, reporting very high levels of support and teacher enthusiasm, with index values of 0.43 and 0.22 , compared to OECD averages of 0.01 . This has important implications: at school level in Brazil, a one-unit increase in teacher enthusiasm correlates with an increase in reading scores of 30 points, compared to an OECD average increase of 8 points. However, students also reported low sense of school belonging and low disciplinary climate which can reduce engagement and inhibit instruction (see Figure 4). Lower secondary teachers in Brazil reported spending 67\% of class time on teaching and learning, compared to $78 \%$ on average, with much of the difference dedicated to keeping order. Furthermore, half of students participating in PISA 2018 in Brazil reported skipping at least one day of school in the two weeks prior to the test, compared to around one-fifth on average; the share reporting exposure to bullying at least a few times a month was also well above average.

Attracting, retaining and developing good-quality school leaders is critical in improving learning environments and promoting effective school leadership. In Brazil, principals are predominantly female (77\%), comparatively young and qualified to Bachelor's level or equivalent (94\%). Selection, appointment and training differ across the country. The PNE formalised intentions to appoint principals on technical merit and performance, yet, in $2018,70 \%$ of municipalities reported resorting to political nomination $\left(2019_{[49]}\right)$. The OECD $\left(2021_{[21]}\right)$ noted that the role remains largely administrative and bureaucratic. Brazil is currently developing a Common National Matrix of Competences for School Leaders (2021[50]) (Matriz Nacional Comum de Competências do Diretor Escolar), expected to be formalised in 2021, which could help address such challenges by clarifying key competencies and responsibilities. Efforts to improve training will also be important. In line with OECD averages, only around one-third of Brazilian principals participating in TALIS 2018 had received instructional leadership or school administration training prior to taking up their role and fewer than average had been trained in teaching or education. The highest reported barriers to participation in continuous professional development (CPD) activities were cost and lack of employer support. Indeed, $81 \%$ of Brazilian principals reported needing more support from the authorities in general, compared to $66 \%$ on average.

A strong supply of highly qualified and engaged teachers is vital in every education system. Common policy priorities for OECD education systems, such as improving teacher qualifications, skills and development, and attracting quality candidates, are also relevant to the Brazilian context $\left(2019_{[51]}\right)$. Teachers in Brazil are young but ageing, predominantly female and mostly qualified to Bachelor's level or equivalent, although the share with a postgraduate qualification is growing. The most common route into teaching is the Bachelor's equivalent degree (licenciatura) in secondary education, or pedagogy for ECEC and primary. Other routes include an upper secondary teaching qualification for ECEC and primary (magistério) or pedagogical complement (complementação pedagógica) for tertiary graduates from other fields. Teaching has not typically attracted high-performing candidates in Brazil: only $30 \%$ of them in 2014 had above-average grades in ENEM (2020[52]). Thus, in the short term, quality initial teacher education (ITE) and CPD to ensure high standards is crucial, while taking steps in the medium term to make the profession more attractive. Brazilian teachers view their ITE positively, with a consistently higher-thanaverage sense of preparedness across all components included in TALIS 2018. Yet, to ensure all trainees receive quality ITE with adequate opportunities for practical application, Brazil will need to monitor and better regulate the growing number of distance providers (see "Governance"). In 2017, 61\% of trainee teachers in Bachelor's programmes were enrolled in a remote degree $\left(2019_{[53]}\right)$. Public school teachers on permanent contracts must be hired through a competition (concurso) administered by states or municipalities, followed by a 3-year probation; the OECD $\left(2021_{[21]}\right)$ has noted that this is rarely a developmental process. Teachers in Brazil have a legal right to CPD (2009). In 2018, 87\% reported participating in at least one CPD activity in the 12 months prior to the TALIS survey and $82 \%$ felt this positively impacted their teaching (OECD averages: $94 \%$ and $82 \%$ ). Increasing CPD participation is a PNE goal but enhancing quality will be critical, too (see "Recent policies and practices").

Teaching conditions in Brazil include larger classes and teaching load, yet teachers are somewhat increasingly satisfied with their career choice. Class sizes decreased from 2005, to 23 and 27 students at primary and lower secondary levels respectively in 2018 (OECD averages: 21 and 23). By law, Brazilian teachers should devote one-third of their working hours to non-teaching activities, yet lower secondary teachers in TALIS 2018 reported spending $75 \%$ of their time teaching. Unlike most OECD countries, only $43 \%$ of lower secondary teachers in Brazil had full-time contracts in 2018 , and $20 \%$ worked in multiple schools; temporary contracts are also common. Teacher contracts and hours worked may therefore limit time spent on CPD, collaboration and school cohesion. Brazil has a National Salary Floor, but career trajectories and pay vary by state. Salaries tend to rise with years of service and further qualification; some states tie increases to management responsibilities, challenging contexts or performance $\left(2019_{[54]}\right)$. In $2017,45 \%$ of municipalities were not complying with the salary floor (2017[55]) and, in TALIS 2018, only $18 \%$ of lower secondary teachers in Brazil reported being satisfied with their salary (OECD average: $39 \%)$. At the same time, $76 \%$ of Brazil's lower secondary teachers reported that they would choose to be a teacher again, equalling the OECD average after increasing by 6 percentage points since 2013 . 


\section{Where does Brazil stand on school improvement?}

\section{Key strengths}

- Students have positive opinions of teachers, according to PISA 2018.

- Despite a growth in demand for teachers and school leaders, there is a high level of tertiary qualified staff.

\section{Key challenges}

- Nurturing more positive learning contexts for students to ensure they do not miss out on valuable learning time.

- Professionalising the school leader role further through enhanced appointment and training processes.

- Providing quality professional development to teaching staff while making the profession more attractive.

\section{Policy efforts in Brazil to move forward}

Brazil's New More Education Programme (Programa Novo Mais Educação, PNME) (2016 $\left.{ }_{[56)}\right)$ is a federal initiative supporting schools to offer after-school extracurricular activities and additional instruction. The programme builds on its predecessor (Programa Mais Educação, 2007), in which participating schools received federal funding to provide extracurricular activities from a prescribed list. After policy evaluations indicated no impact on learning or completion rates $\left(2015_{[57]}\right)$, MEC introduced the PNME to provide additional learning in core subjects too. The programme targets low-performing schools in vulnerable communities. Schools must administer diagnostic assessments and record results in a centralised platform. They then receive pedagogical feedback to use these results to inform planning. Analysis of international policy responses to COVID-19 suggests that this is promising practice in efforts to recover learning (2020[2]); as such, the PNME could be particularly important as schools reopen. Similar international policy initiatives indicate that there may be potential for this programme to further harness resources and expertise among local communities to extend the educational offer further without burdening school professionals [Read More].

To support the implementation of the BNCC (see Spotlight 4), Brazil introduced new National Curriculum Guidelines for ITE and a Common National Base for ITE (2019[58) (BNC-Formação), plus National Curriculum Guidelines for CPD and a Common National Base for CPD (2020 [59) (BNC-Formação Continuada). These steering documents establish professional standards for ECEC, primary and secondary teachers aligned with the BNCC. Teacher competencies cover three interdependent domains: knowledge - mastering content; practice - managing classrooms; and engagement - interacting with stakeholders. Each domain contains specific skills, introduced in BNC-Formação and extended in BNC-Formação Continuada. The documents also establish guiding principles: for ITE these emphasise the need for practical experience, innovation and evidence-based practice. This is important as, currently, teacher candidates must opt in to additional programmes to get extended practical classroom experience. The Institutional Programme for Teaching Initiation Scholarships (Programa Institucional de Bolsa de Iniciação à Docência, 2012), provides scholarships to students who undertake a weekly workload in a public school and the Pedagogical Residency Programme (Programa Residência Pedagógica, 2018) gives candidates 440 hours' experience in schools. The BNC-Formação Continuada promotes school-embedded, collaborative and active learning. However, it remains to be defined how MEC will hold schools, HEls and other providers accountable for implementing new guidelines (2021 [21]), particularly as the majority of ITE and CPD now occurs through distance programmes offered by private providers, which are less well-regulated (see "Governance") $\left(2018_{[13]}\right)$. An implementation plan, co-ordinated with subnational actors and HEls, and clearly delineating roles and responsibilities, could serve to define a more transparent and shared approach to implementation, against which progress can be monitored on an ongoing basis.

The state of São Paulo's Modernisation of the Teacher Career policy (Modernização da Carreira Docente) (2019[60]), aims to enhance the attractiveness and quality of the profession. The policy aims to raise initial salaries by $54 \%$ until 2022 and reduce the number of salary steps from 64 to 15 . More emphasis will be placed on quality criteria for progression, such as class observation and feedback, as well as length of service and qualification. Implementation was stalled by a freeze on public spending increases during the pandemic. Going forward, monitoring the impact of salary increases on recruitment, retention and teacher quality will be critical: evidence from international salary reforms indicates that this has often been neglected despite the costliness of such measures (2019[51]).

In Rio Grande do Sul, the Internal Commissions for the Prevention of Accidents and School Violence (2012[61]) (Comissão Interna de Prevenção à Acidentes e Violência Escolar, CIPAVE) support schools to identify negative behaviours among students, their causes and frequency, and to seek preventative action. Through incidence mapping, CIPAVE also identifies wider trends; this was strengthened with the launch of CIPAVE+ (2020), a digital platform to facilitate monitoring and collaboration. CIPAVE is based on mobilising local partnerships, an approach which has been identified as a feature of impactful international policy efforts to enhance learning environments (2019[51]) and helps promote responsiveness and resilience. School-based commissions establish links with local actors from a range of relevant services identified by the state, such as the police or fire departments and non-governmental organisations. CIPAVE became a state priority policy in 2015; by 2019 it was credited with having reduced instances of school violence by $65 \%$. Impact remains varied, however: pressure on resources and technical support can inhibit progress (2019[62). 


\section{Spotlight 3. Strengthening the role of digital technology in education in Brazil}

Digital technology has an important role to play in education in Brazil, with the potential to support the expansion of participation and attainment, and enhance learning. As such, Brazil has long engaged in policy efforts to expand the role of digital technology within the system. These efforts can be organised into four main categories:

- Establishing a clear vision: The National Programme for Informatics in Education (Prolnfo, 1997-2007; Prolnfo Integrado, 2007-17) provided long-term policy efforts in digital education. Recently, Brazil has introduced more strategic efforts: the PNE includes several objectives for advancing digital skills and using information and communications technology (ICT) to improve outcomes. The Brazilian Digital Transformation Strategy 2018-21 (E-Digital), an interministerial initiative, integrates governmental programmes under one framework. Education and training is one of five axes; objectives include forming a national education technology policy, expanding school broadband, improving training, producing pedagogical resources and enhancing digital skills through the NEM and BNCC.

- Developing quality digital infrastructure: Prolnfo Integrado provided federal support to states and municipalities to increase the availability of ICT infrastructure and equipment through establishing ICT labs in ECEC settings and schools. MEC recently reinvigorated these efforts with the launch of the Connected Education Innovation Programme (Programa de Inovação Educação Conectada, PIEC, 2017) absorbing many of the initiatives under Prolnfo and expanding efforts further. Brazil aims to universalise access to high-speed internet in all schools by 2024, including those in which terrestrial connection is not feasible. Currently, approximately 2.4 million students are benefitting from the programme. The Connected North (Norte Conectado, 2020) project aims to connect remote regions across the Amazon rainforest.

- Strengthening educators' digital skills: Prolnfo Integrado also developed teacher training. Through Educational Technology Hubs (Núcleos de Tecnologia Educacional), and in partnership with HEls, courses to develop teachers' digital skills and pedagogy were offered across Brazil. This has been identified as Prolnfo's major legacy. More recently, the New Pathways programme (see "Preparing students for the future") introduced post-graduate specialisations in teaching VET through distance modalities and a massive open online course to support better mentoring and guidance in VET.

- Providing digital content and resources: Some states have adopted online learning to raise upper secondary participation. The Media Education Centre of Amazonas (Centro de Mídias de Educação do Amazonas, 2007) targets rural students facing teacher shortages, broadcasting live teacher-led classes to students supported by in-person tutors. This helped halve upper secondary drop-out rates and is now used at other levels too. More recently, MEC's Integrated Platform of Digital Educational Resources gathers digital content from the main education portals across Brazil, combining elements of an open resource library and a professional network. MEC's AVAMEC platform (2019) makes online courses from across Brazil available nationally; user numbers increased by $154 \%$ between February and April 2020 during the COVID-19 pandemic. In tertiary, online delivery is increasingly common: from 2017-19, the number of distance undergraduate courses more than doubled, mostly in the private sector where $51 \%$ of new entrants enrolled in distance courses in 2019. Public HEls can deliver up to $40 \%$ of a course remotely; MEC is currently developing an Expansion Plan for Digital Higher Education (2020). Brazil has also established a Technical Committee for the Monitoring of Distance Education Policy (2020) for VET. The use of online teacher training is widespread largely through the Open University of Brazil Programme (2006) under the Foundation for the Coordination of Improvement of Higher Education Personnel. In 2021, over 75000 trainee teachers trained through distance mode and nearly 17000 were enrolled in distance CPD courses.

Data collected by the OECD prior to the COVID-19 pandemic indicate that for Brazil to harness the full potential of digital technology in education, access needs strengthening, and digital divides must be narrowed. According to self-reports in PISA 2018, only around one-quarter of school principals in Brazil agreed that internet bandwidth in their school was sufficient, compared to over two-thirds on average across the OECD. Differences between advantaged and disadvantaged schools were among the widest of all countries participating in PISA. Research indicates that Prolnfo did improve teacher skills, but was less able to provide a clear vision and deliver on infrastructure targets. PIEC, to which MEC's commitment increased during COVID-19, could overcome this but must be mindful of inequities. In 2018, PIEC mostly benefitted urban settings; the North Connected project indicates an emerging focus on rural areas. Going forward, it will be important that PIEC integrates good practices and lessons learned during the pandemic period, when the role of digital technologies in education increased greatly. Given the recent explosion in digital modalities accelerated by institutional closures during the pandemic, this should prioritise improving educators' skills, confidence and the tools available to them to apply digital technology in a way that drives up the quality of teaching and learning.

Sources: Cruz, P. et al. (2016[63]), Media Center: Innovating with Distance Learning in Amazonas, Brazil, Center for Universal Education, Brookings, Brookings Institution, Washington D.C.; INEP (2019[64]), Censo da Educação Superior 2019: Divulgação dos Resultados [Higher Education Census 2019: Dissemination of Results], INEP, Brasília; OECD (2020[14]), Going Digital in Brazil, OECD Publishing, Paris; Presidência da República (2018[65]), Estratégia Brasileira para a Transformação Digital [Brazilian Strategy for Digital Transformation], Presidência da República Brasília; Valente, J. A., and M. Almeida (2020[66] ), "Brazilian technology policies in education: History and lessons learned", Arquivos Analiticos de Políticas Educativas, 28(94), https://doi.org/10.14507/epaa.28.4295. 


\section{EVALUATION AND ASSESSMENT: BRAZIL HAS STRONG SYSTEM-LEVEL EVALUATION, BUT ROOM FOR MORE FORMATIVE APPROACHES IN INSTITUTIONS}

Defining strategies for evaluation and assessment is an important step towards improving student outcomes and developing a better and more equitable education system. System evaluation can provide evidence to help decision makers craft informed policies and increase the transparency of education system outcomes. At federal level, system evaluation consists of the National System for Evaluation of Elementary Education (SAEB) and the National Higher Education Assessment System (SINAES). They are overseen respectively by the National Institute for Educational Studies and Research (INEP) and the National Higher Education Assessment Commission (CONAES). INEP also conducts annual censuses of basic and higher education, and produces other evidence to support policy processes. Many states and municipalities also administer their own standardised assessments of student learning. According to INEP (2018[67]), most follow formative principles using assessment as an education management tool, but could focus more on input- and process-related quality indicators. Brazil also participates in several international assessments of student learning. Overall, better articulation between system monitoring assessments at different administrative levels could enhance efficiency; recent efforts in ECEC and VET (see "Recent policies and practices") should be considered for alignment too. Thus, as previously identified for many education systems across the OECD (2019[51]), developing a coherent evaluation and assessment framework covering the full education system is a priority for Brazil.

Brazil's system evaluation tools feed into school evaluation and monitoring. The National Education Quality Index (IDEB), based on SAEB results and indicators related to student transitions, provides performance scores at school, municipal, state or national level from primary to upper secondary education. These are then used to inform improvement planning and performance targets at each of these levels. In PISA 2018, a similar share of Brazilian principals as on average among their peers in OECD countries indicated that schools are likely to conduct self-evaluation (96\% compared to $95 \%$ ). However, it is less likely to be mandatory in Brazil. External school evaluation is more common in Brazil than on average and more likely to be mandatory. The OECD (2014[9]) previously reported that IDEB helped foster greater focus on school quality and improvement. However, more recently, the OECD (2021[21]) noted that it could be strengthened to more fully capture key system challenges such as equity and balance increasingly high-stakes uses. Indeed, TALIS 2018 data indicate that Brazilian educators feel related pressure: $52 \%$ of teachers and $67 \%$ of principals reported being held responsible for students' achievement as a key cause of stress, compared to $44 \%$ and $46 \%$ on average. This may negatively impact teachers' attitudes towards their careers and the attractiveness of the profession (see "School Improvement").

According to OECD evidence, teacher appraisal can strengthen professionalism and performance if it includes both improvement and career progression components. In Brazil, appraisal is not obligatory, nor are there national guidelines or common teacher standards. Many states and municipalities have appraisal policies in place, although a comparative study $\left(2019_{[68]}\right)$ found that of 24 states with such policies, only 14 were enforced. Nevertheless, TALIS 2018 data indicate that Brazilian teachers are evaluated regularly: $77 \%$ of lower secondary teachers' principals reported formally appraising their staff compared to an OECD average of $63 \%$. Furthermore, appraisal appears more development-focused in Brazil: larger-than-average shares of teachers had principals who reported that, following appraisal, they mostly or always hold discussions to address weaknesses in teaching $(93 \%$ compared to $63 \%$ ) and produce a development plan (60\% compared to $46 \%)$. At the same time, several state policies have higher-stakes outcomes for teacher appraisal, such as consequences for career progression or remuneration, and teacher attendance and student performance in external evaluations are the most common evaluation criteria, as opposed to the observation of teaching practice $\left(2019_{[68]}\right)$. Yet in Brazil, as elsewhere, in TALIS 2018, teachers were more likely to consider the feedback they received to be impactful when it was based on classroom observation. Moving forward, Brazil should consider efforts to increase consistency in appraisal practices, ensuring a focus on formative approaches.

Strong student assessment practices can inform and shape effective initiatives for educational improvement. As of 2019, through SAEB, Brazil administers biannual national standardised assessments in Portuguese and mathematics in Years 2, 5, 9 (when natural and human sciences are also assessed) and Grade 3. Accompanying questionnaires help contextualise the results. Students also sit the ENEM at the end of upper secondary (see "Preparing Students for the Future"). Revisions to both are an urgent priority for Brazil to support the implementation of the NEM and BNCC (see Spotlights 2 and 4). Tertiary students sit the mandatory National Examination of Student Performance (ENADE) to assess knowledge and skill acquisition, administered in three-year cycles. The OECD has reported a need to re-evaluate the objectives and design of ENADE to ensure that it is fit for purpose (2018 [13]). The central role of all of these standardised assessments in Brazil's evaluation and assessment framework makes improving them a priority. At the same time, evidence suggests room to enhance more formative approaches to student assessment. In 2018, in comparison to OECD averages, lower secondary teachers in Brazil reported providing written and immediate feedback to students more frequently but students perceived receiving it less frequently, with an index value of -0.16 , compared to 0.01 . Principals' perceptions of parental involvement in discussions on student progress were also below average. Analysis of international evidence and COVID-19 policy responses indicate that formative assessment and feedback support learning recovery (2020[2]). As schools in Brazil reopen and attention shifts to remediation, supporting teachers to diagnose learning losses and conduct formative assessment will be key. International approaches to the COVID-19 recovery can help serve as inspiration in this regard [Read More]. 


\section{Where does Brazil stand on education evaluation and assessment?}

\section{Key strengths}

- Evaluation infrastructure is in place at federal level to provide information on system performance in school and tertiary education, and is emerging in other areas.

- Within a decentralised system, national quality indicators for schools help offer some consistency.

\section{Key challenges}

- Supporting educators to engage with monitoring and evaluation data for school and professional improvement that is constructive and does not cause excess stress.

- $\quad$ Strengthening the use of student assessment to support learning through a more formative focus.

\section{Policy efforts in Brazil to move forward}

In 2018, MEC published National Quality Parameters of Early Childhood Education (2018[69) (Parâmetros nacionais de qualidade da educação infantile, 2018) as a guideline from which subnational networks develop policies, tools and monitoring and evaluation mechanisms to improve ECEC quality. The Parameters aim to harmonise, update and expand the scope of previous documents: the National Parameters for the Organisation and Functioning of ECEC settings (2006) and Quality Indicators in Early Childhood Education (2009 $\left.{ }_{[70]}\right)$. They cover 8 areas: 1) management of systems and networks; 2) staff training, careers and remuneration; 3) management of settings; 4) curricula and pedagogy; 5) interaction with family and community; 6) inter-sectoral collaboration; 7) physical resources; and 8) infrastructure. Compared to previous documents, inter-sectoral collaboration is a positive addition, aligning with wider ECEC efforts (see "Governance"). The Parameters were developed in collaboration with national and subnational actors and non-governmental organisations (NGOs) and are designed to allow for local adaptation. It is unclear how implementation is monitored at federal level: the use of participation rates, as for monitoring PNE goals, for example, may not sufficiently capture information about quality. International policy experiences can provide some further insights [Read More].

Brazil has also worked to improve the dissemination and use of school-level evaluation and monitoring data. The IDEB by School (IDEB por Escola) platform (2020[71]), allows users to combine IDEB 2019 results with data on individual school contexts (e.g. infrastructure, resources and pedagogical organisation) and compare IDEB results by groups of schools with similar characteristics. In addition, the Click School (Clique Escola) application (2020 723$)$ allows users to access individual schools' SAEB results, age-grade distortion rates, class sizes, teacher qualifications, and completion and non-completion rates. It also publishes data from the PDDE to make the distribution of federal resources to schools more transparent. At the same time, MEC is strengthening PDDE Interactive (2012) a school management tool that supports with planning and budget management. These are important steps in nuancing school performance data, given the increasingly high-stakes consequences of IDEB results (2021 [21]).

The National School Health Survey (2009) (Pesquisa Nacional de Saúde do Escolar, PeNSE) (n.d. .733) is a collaboration between the Ministry of Health, the Brazilian Institute of Geography and Statistics, and MEC. In 2009 and 2012 a nationally representative sample of students in Year 9 were surveyed on their social and family contexts, behavioural risk factors, sexual and reproductive health, exposure to violence, and mental health, among others. Coverage expanded in 2015 and by 2019 covered Years 7-9 and Grades 1-3. Basic socio-economic and school characteristics are also considered, including school physical environment, and behaviour and health policies. Although PeNSE provides essential information to guide public policy, results from 2019 have not yet been published. There is evidence that student voice initiatives have gained importance internationally during $2020\left(2020_{[2]}\right)$. Given the prolonged school closures in Brazil, and the ongoing challenge to ensure positive learning environments, enhancing the PeNSE's outputs further could help tailor policy initiatives to students' lived experiences and make well-being a priority (2020[74)

The new Monitoring and Evaluation Plan of the VET offer $\left(2020_{[75)}\right)$ establishes pedagogical and institutional indicators to analyse results obtained by VET providers, including quarterly quantitative monitoring, and qualitative evaluation informed by site visits and stakeholder feedback. Brazil also introduced new regulations for VET courses offered by private HEls (2019 [76]; 2020[77) and established a committee to develop recommendations for monitoring the quality of distance provision in VET education (see Spotlight 3). As very recent efforts, evidence of progress and impact has not yet materialised. However, ongoing efforts to enhance system evaluation components in VET are a positive move towards increasing quality and consistency across the sector.

The municipal authority of Boa Vista, in collaboration with researchers and an NGO, aims to enhance ECEC quality by collecting and operationalising diagnostic data on child development and learning environments. For this, the team adapted the Measuring Early Learning Quality and Outcomes (MELQO) (2017 788$)$ questionnaire, an international assessment tool, including by ensuring alignment with the BNCC. Following a pilot in 2018 to strengthen system evaluation through developing information management systems (2019[51]), in 2019, Boa Vista developed an online ECEC monitoring platform through which educators and managers can use the data to support their work. This involved consultation, prototyping then adjustment $\left(2020_{[79)}\right)$. These efforts to balance data collection with a focus on dissemination and use is critical in developing responsive and resilient data systems (forthcoming[27]); close monitoring of the success of the policy could help other municipalities in Brazil identify lessons for local implementation. 


\section{GOVERNANCE: BRAZIL HAS A COMPLEX NETWORK OF ACTORS WHO COULD BENEFIT FROM MORE CLEARLY DEFINED RELATIONSHIPS}

System governance in Brazil is highly decentralised across federal government, 27 states and 5570 municipalities; Brazil's size and diversity add further complexity. Each governance level can legislate and develop policy but MEC steers the system through national standards and frameworks. MEC co-ordinates national education policy, regulates and evaluates the system, and provides financial and technical assistance to states and municipalities to promote equity and quality (see "Recent policies and practices"). In principle, Brazil's system of shared governance is non-hierarchical, but federal government has typically enacted top-down policies (2020[80]). This may inhibit efforts to raise equity and quality which require responsiveness to local realities. Therefore, clarifying the division of responsibilities between authorities and schools, the most common policy priority among OECD countries in 2008-19 (2019[51]), is highly relevant for Brazil too. Legislative proposals to address this through a National Education System (Sistema Nacional de Educação) are currently awaiting assessment. MEC collaborates with other ministries, notably in ECEC, VET and research. Other relevant national level bodies include:

- The National Council of Education (Conselho Nacional de Educação, CNE), a collegiate advisory body to the MEC responsible for legislation compliance and quality standards for all education levels;

- The National Institute of Educational Studies and Research Anísio Teixeira_(Instituto Nacional de Estudos e Pesquisas Educacionais Anísio Teixeira, INEP), a semi-autonomous agency for monitoring and evaluation;

- The Foundation for the Co-ordination of Improvement of Higher Education Personnel (Coordenação de Aperfeiçoamento de Pessoal de Nível Superior, CAPES), responsible for graduate programme evaluation;

- The National Committee for the Evaluation of Higher Education (Comissão Nacional de Avaliação da Educação Superior, CONAES) evaluates and supports the development of tertiary education;

- The National Council of State Education Secretaries (Conselho Nacional de Secretários de Educação, CONSED) and the National Union of Municipal Education Managers (Education União Nacional dos Dirigentes Municipais de Educação, UNDIME), collegiate bodies for subnational authorities;

- The National Association of Directors of Federal Institutions of Higher Education (Associação Nacional de Diretores de Instituições Federais de Ensino Superior, ANDIFES) and National Association of Private Universities (Associação Nacional das Universidades Particulares, ANUP), tertiary-level stakeholder bodies.

Systematic, comprehensive stakeholder engagement is a stated goal of the PNE. In addition to CONSED, UNDIME, ANDIFES and ANUP, Brazil has several formal spaces for stakeholder participation in education policy making (e.g. the National Conference on Education, the National Forum on Higher Education) which regularly convene subnational representatives, civil society and professional organisations, and can have decision-making power. In 2019, formal stakeholder participation channels existed in all states and about $90 \%$ of municipalities $\left(2020_{[18]}\right)$. At school level, in TALIS 2018, Brazilian principals reported greater interaction with students, families and the local community or businesses than on average across the OECD, at $41 \%$ of working time compared to $29 \%$. During the COVID-19 pandemic, CONSED and UNDIME played an important role in supporting states and municipalities with technical support, working to co-ordinate an agenda to guide educational actors.

Public delivery prevails at ECEC and school level in Brazil but, in 2019, the private sector enrolled nearly $30 \%$ of children in ECEC and around $20 \%$ of school students. At these levels, subnational authorities are responsible for the management of financial resources and teachers; municipalities primarily oversee ECEC, primary and lower secondary education, and states manage lower and upper secondary. Administrations vary greatly in size, organisation, capacity and resources, which causes marked inconsistencies. Developing more horizontal collaboration could help overcome this (2020[80]) (see "Recent policies and practices"), as could formal, competitive selection processes for key staff in subnational administrations, as already tried in some states and municipalities. Legally, all schools have pedagogical autonomy. Nevertheless, in TALIS 2018, while large shares of lower secondary principals in Brazil reported having autonomy in decisions related to student discipline and admissions, smaller shares reported the same for course offer (9\%) or content $(20 \%)$, for example (See Figure 6). This, along with challenges relating to school leader and teacher capacity and working conditions (see "School Improvement"), may limit schools' ability to improve quality while also making it harder to overcome inconsistencies between administrative regions. In this regard, the BNCC can play an important role, helping to guide instructional practice and reduce quality differences between schools.

Public higher education is predominantly a federal responsibility, with some state-managed HEls; private institutions enrolled $75 \%$ of all tertiary students in 2019. The federal government defines the national strategy for the sector and oversees quality assurance and licensing. Institutional autonomy is guaranteed but civil service regulations apply to academic staff in public HEls whereas private HEls have more autonomy in this regard. The OECD has found that Brazil's quality assurance system for this education level ensures HEls meet a minimum level of quality but does not incentivise improvement (2018[13]); international examples offer further insights [Read More]. The growth of distance learning (see Spotlight 3) requires better oversight and regulation: the evaluation criteria currently applied are limited in number and scope and could better consider the unique challenges facing these modalities (2018[13]). 


\section{Where does Brazil stand on education governance?}

\section{Key strengths}

- The federal government plays an important role in steering the system, establishing guidelines or standards in pursuit of greater consistency.

- Brazil engages a wide range of stakeholders in education governance and this is formally stated as a national priority.

\section{Key challenges}

- Ensuring coherence and alignment across all actors to support more effective and equitable policy implementation.

- Establishing and promoting vertical and horizontal collaboration structures that support quality improvement.

- Enhancing quality assurance in distance education

\section{Policy efforts in Brazil to move forward}

Establishing national strategies and plans was by far the most frequent policy tool reported by OECD education systems between 2008 and 2019. It was also identified as being particularly valuable when long-term national goals are broken into shorterterm actions and sub-actions with concrete outputs, which then informs policy decision making across the system (2019 $\left.{ }_{[51]}\right)$. Through the National Education Plan (2014[81]) (Plano Nacional de Educação, PNE), Brazil adopts much of this good practice. The PNE outlines 20 goals to be achieved by 2024, based on which states develop locally responsive plans. Developed over four years, and under discussion for much longer, it represents an important achievement in establishing a consensus-based vision of a better education system for Brazil. INEP regularly monitors progress, publishing findings every two years. By $2019,12 \%$ of the 52 quantitative indicators had been achieved, and the average achievement rate was $75 \%$. Recognising the high ambition of many of the goals, and Brazil's challenging economic context since 2014, this is a significant feat. Nevertheless, INEP's latest evaluation indicates that, at the current rate of progress, many goals will not be realised by 2024 and geographic inconsistencies and other inequities exist for the majority $\left(2020_{[18]}\right)$. As Brazil works to control and then recover from the COVID-19 pandemic, the context becomes even more challenging. The PNE therefore continues to provide an important roadmap that must clearly and consistently inform policy decisions.

Brazil's Legal Framework for Early Childhood (2016[82]) (Marco Legal da Primeira Infância), which guides public policy making for 0-6 year-olds, takes a holistic view, promoting inter-sectoral co-ordination. As a result, the federal government, several states and a number of municipalities created inter-sectoral policies and programmes for early childhood; some integrate 3 sectors (e.g. education, health and social assistance) and others up to $15\left(2020_{[33]}\right)$. While such collaborations may have fostered some greater synergies between public services, it is also important that roles and responsibilities are well-defined from the outset. Furthermore, integrated approaches to data collection and management have been less prevalent, and the potential of integrated funding not yet realised. As these initiatives move through the system, efforts to enhance the co-ordination of public services at local level can help strengthen responsiveness and resilience in students, institutions and education systems (forthcoming[27]).

The Articulated Action Plan (2012[83]) (Plano de Ações Articuladas, PAR) is a strategic planning tool for states and municipalities which has become the main instrument for transferring federal technical and financial support to subnational networks. In four-year cycles, states and municipalities conduct a self-diagnosis through a participatory process using a digital platform, Simec, then develop an action plan. This is presented to MEC, with whom a letter of agreement is signed. Although not mandatory, the PAR is a condition for obtaining MEC assistance through the National Education Development Fund (see "Funding"). Identified strengths include greater transparency or fairness in the allocation of federal resources, and a stronger collaboration regime between federal and subnational levels, and subnational and school levels (2020[84]). Using Simec helped increase efficiency and enabled adaptations to be easily introduced based on feedback. Areas identified for improvement include narrowing the scope of and regularly updating the priority policies around which the PARs are developed, and improving the monitoring and evaluation of resource use (2020[85]).

Efforts are growing to support horizontal collaboration among municipalities. Brazil introduced the Education Development Arrangements (2012[86]) (Arranjos de Desenvolvimento da Educação, ADEs) encouraging neighbouring municipalities, public agencies, and private and non-governmental institutions to work together to enhance public management for educational improvement. Municipalities seeking to form an ADE are encouraged to undertake a mapping of potential partners in the common area then develop a strategic plan formally agreed upon by all participants. In Santa Catarina, 21 municipalities have been collaborating since 2015 on initiatives such as training for teachers, school leaders and municipal secretaries, with an increasingly positive impact on IDEB results; a new municipality joined in $2021\left(2021_{[87]}\right)$. The OECD $(2020[80])$ reported that long-term financial sustainability and lack of formal federal guidelines or regulation are challenges to ADE formation and operation. Municipalities can also form legally-recognised consortia, meaning they can, for example, undertake intermunicipal purchases and mutual hiring processes. These can operate in any sector of municipal responsibility; only a few are active in education, but many have signalled interest in expanding into this area $\left(2^{2019}{ }_{[88]}\right)$. In 2017, an Intermunicipal Network for Collaboration in Education was established to support ADEs and consortia to share best practices. The current context creates further impetus for collaboration as the economic consequences of COVID-19 and the demanding implementation of large-scale reforms make efficiency and collaboration key pursuits. 


\section{Spotlight 4. Establishing a base curriculum to harmonise a highly decentralised system (2017)}

In 2013, Brazil began a process of ambitious curricular reform to establish nationally-agreed essential learning outcomes. In late 2017, the National Common Curricular Base (Base Nacional Comum Curricular, BNCC) for ECEC to lower secondary (ages 0-14) was approved, with upper secondary (ages 14-17) added in 2018. The BNCC acts as a national reference point from which state and municipal curricula and school pedagogical programmes, responsive to local social, economic and cultural context, are formed. Brazil intends to align teacher training, standardised assessment and pedagogical resources across the country with the BNCC, making it the base reference for educational coherence and collaboration within a decentralised system. It also aims to reduce the influence of national standardised assessments and textbooks on classroom curricula, promoting flexibility and adaptation.

Momentum for establishing the BNCC was initially driven by a non-governmental coalition of education actors and organisations (Movimento pela Base, 2013); ambitions were formalised in Goal 7 of the PNE. A broad commission of representatives from schools, HEls and subnational authorities prepared a first version in 2015, then submitted to public consultation and expert analysis. In 2016, MEC established management and writing committees to lead revision processes and conducted several workshops with subnational actors for feedback on version two. Version three was put to relevant third sector organisations, unions and HEls across Brazil.

Once approved, implementation fell to states and municipalities, with MEC in a co-ordinating, supporting role. Based on the BNCC, subnational authorities were to develop their own curricula, offering introductory teacher training, support for school implementation and aligning pedagogical material. Full implementation was planned for 2020 in ECEC, primary and lower secondary and from 2022 in upper secondary. To deliver financial and technical support, MEC established the Programme for the Implementation of BNCC (ProBNCC, 2018) in collaboration with subnational representatives, funding staff (curriculum writers, co-ordinators and staff dedicated to strengthening collaboration between states and municipalities), training and other supports.

Important progress has been made. From 2018-20, MEC assigned over 1500 ProBNCC scholarships and by the end of 2020, all states and $81 \%$ of municipalities had aligned their ECEC, primary and lower secondary curricula to the BNCC; upper secondary alignment is ongoing. There has been some positive collaboration with many municipalities adopting state curricula to help streamline resources. Based on the BNCC, in 2019, Brazil approved new national guidelines for teacher professional development (see "School Improvement") and updated parts of the SAEB assessments (Years 2 and 9). MEC has also approved new textbooks aligned with BNCC for ECEC, primary and lower secondary teachers and students. This is positive, as international analysis of curriculum implementation shows that alignment with other policy areas is key in securing stakeholder buy-in, capacity building and engagement.

However, implementation slowed in 2020, particularly ProBNCC and upper secondary curricular adaptation, partly due to the COVID-19 pandemic and partly due to less direct federal leadership. Subnational and third sector organisations tried to fill this gap: the Observatory for the implementation of BNCC and NEM (2020), founded by Movimento pela Base with support from subnational representative bodies, gathers and publishes progress data and analysis. Close collaboration between federal and subnational authorities was also less prevalent. Without federal steering, Brazil risks delaying implementation and exacerbating inconsistencies. By late 2020, however, the situation was improving: MEC, in collaboration with subnational actors published an implementation guide with proposed timelines and action plans. MEC also announced stage one of implementation diagnosis, including developing its own monitoring platform and conducting stakeholder surveys. MEC and civil society actors should now work together in these efforts. The updating of SAEB and ENEM to align with the BNCC is the most immediate priority. Not only will this help clarify expectations for subnational actors, but these assessments can then act as useful tools for monitoring curricular implementation (2021 [89]).

Still, Brazil faces further challenges, not least alignment with other reforms, and more coherence in teaching material. As a federal responsibility, textbook updates may not fully respond to subnational needs, and many states and large municipalities, including high-performers, produce their own additional materials, creating inefficiencies. While school closures complicated implementation, and the prolongation of the pandemic puts pressure on resources, the COVID-19 experience may also be an opportunity on which to rebuild implementation momentum. As schools reopen, the BNCC needs to inform a reference for minimum requirements to guide learning recovery. At the heart of this should be strong collaboration across all levels of the system. International evidence indicates the positive impact this can have for successful curriculum implementation, including in building teachers' confidence in applying new curricula [Read More].

Sources: Fernandes dos Santos, A. and M. Ferreira, (2020[90]), Base Nacional Comum Curricular, Qualidade da Educação e Autonomia Docente [National Common Curricular Base, Educational Quality and Teachers' Autonomy], INEP, Brasília; Gouëdard, P. et al. (2020[91]), "Curriculum reform: A literature review to support effective implementation", OECD Education Working Papers, No. 239, OECD Publishing, Paris; MEC (2018[92]) Base Nacional Comum Curricular [National Common Curricular Base], MEC, Brasília; Movimento Pela Base (2021[93]), Movimento Pela Base - Início [Movement for a Core Curriculum - Home], https://movimentopelabase.org.br/ (accessed on 24 February 2021); OECD (2019[51]), Education Policy Outlook 2019: Working Together to Help Students Achieve their Potential, OECD Publishing, Paris; Todos pela Educação (2021 [94]), $2^{\circ}$ Relatório Anual de Acompanhamento do Educação Já! [2nd Annual Monitoring Report for Education Now!], Todos pela Educação, São Paulo. 


\section{FUNDING: BRAZIL HAS SHOWN COMMITMENT TO PROTECTING EDUCATION FUNDING AND REDISTRIBUTON, BUT INEFFICIENCIES REDUCE IMPACT}

Among OECD education systems from 2008-19, enhancing the efficiency and equity of education spending were key policy priorities $\left(2019_{[51]}\right)$. Both are also highly relevant in the Brazilian context. Brazil's overall expenditure on education, as a proportion of national wealth, is high by international comparison. In 2017, Brazil dedicated $5.1 \%$ of gross domestic product (GDP) to education ${ }^{4}$ (OECD average, $4.1 \%$ ). Furthermore, this share increased considerably from 2005, concurrent with increases in GDP itself. Recently (2012-17), the share of spending on tertiary education continued growing despite economic downturn, whereas primary, secondary and post-secondary non-tertiary funding stagnated. Indeed, in 2017, per-student spending across primary, secondary and post-secondary education in Brazil was well below the OECD average, at USD 3875 compared to USD 9515. In contrast, per-student spending at tertiary level was above the OECD average and over four times that of students in lower levels. The OECD average difference was 1.4 times higher. Furthermore, analysis of MEC's spending indicates that 2020 saw the lowest budget and execution rate for compulsory education since 2010 (2021[95]). Research also indicates that, historically, the share of funding to ECEC has been low (2019[96]; 2018[97]). As the economy looks set to contract further following the COVID-19 pandemic, some reprioritisation across levels could benefit Brazil.

Brazil has made efforts to guarantee some basic educational funding. States and municipalities must designate $25 \%$ of tax revenue and federal transfers to the sector and, until 2017 , at least $18 \%$ of federal revenue had to go to education. Following efforts to stabilise public debt, this spending floor was adjusted, taking federal expenditure on education in 2017 as the minimum value until 2036, with adjustments for inflation. Through Brazil's education salary (salário educação), $2.5 \%$ of companies' salary contributions must go to compulsory education, through the National Education Development Fund (Fundo Nacional de Desenvolvimento da Educação, FNDE) and states and municipalities. Also, as of $2013,75 \%$ of revenue from exploration in oil and natural gas industries must go to education. The PNE established a goal of spending 10\% of GDP on education by 2024 . As pressure on public finances increases in the context of COVID-19, Brazil should protect these mechanisms while ensuring they produce the intended effects: a focus on expenditure targets without impact requirements may contribute to inefficiencies $\left(2020_{[15]}\right)$ and there is a need for more robust monitoring and accountability, tying education spending to outcomes $\left(2021_{[21]}\right)$. Ongoing efforts to strengthen PDDE Interactive could contribute to this (see "Evaluation and Assessment").

In Brazil, funding for public ECEC, primary and secondary schools comes predominantly from states and municipalities who are responsible for staff remuneration, building maintenance and educational resources, as well as activities to strengthen provision. In $2018,42 \%$ of initial funding for primary, secondary and post-secondary nontertiary education came from states, $44 \%$ from municipalities and $14 \%$ from central government, with most of the latter then transferred to municipalities. Decentralisation combined with strong regional socio-economic variation has resulted in large funding disparities between and within states. Several national redistributive measures are in place, notably Fundeb (Fundo de Manutenção e Desenvolvimento da Educação Básica e de Valorização dos Profissionais da Educação, 2007 and 2020) (see "Recent policies and practices") which builds on objectives established in 1996 with the approval of Fundef. The FNDE's Direct Money to Schools Programme (Programa Dinheiro Direto na Escola, PDDE), distributes federal funds to schools to support educational activities and reform processes and is partly weighted by school context (type and location), though not students' socio-economic context. Still, inequities remain and while, according to school principals in 2018, the index of material shortages in advantaged schools is much lower in Brazil than the OECD average (-0.83 compared to -0.21$)$, that of disadvantaged schools is much higher ( 0.51 compared to 0.15$)$, for example (see Figure 7$)$. Brazil also faces efficiency concerns, particularly related to teacher quality and high grade repetition and drop-out rates. Based on data from 2009-13, the World Bank (2017 [55]) estimated that if all networks operated at the level of the most efficient, Brazil could increase student attainment and achievement by $40 \%$ in primary and lower secondary and $18 \%$ in upper secondary without further public investment. Performance-based funding mechanisms as pioneered in some states may support this (see "Recent policies and practices").

In public higher education, federal funding constitutes $75 \%$ of initial funds, states provide $24 \%$ and municipalities $1 \%$. MEC allocates operating budgets to HEls annually, based on historical patterns (current expenditure) and formulas (capital expenditure). State-level HEls receive state funds and tend to have greater autonomy managing them. Public HEls cannot charge tuition fees but $75 \%$ of tertiary students are enrolled in private institutions which can, and do. This is regressive, as disadvantaged students disproportionately attend private HEls (see "Preparing Students for the Future"); scholarship and loan schemes help partly alleviate this (see "Recent policies and practices"). Per-student spending in the public sector is much higher than that in the private sector, even when accounting for research and development funding, and associated higher student outcomes appear largely due to higher performance levels on entry $\left(2017_{[55]}\right)$. Therefore, there is room to enhance efficiency and equity in Brazil's higher education funding. In other OECD countries, where large-scale funding reforms of this nature have been introduced, evidence of progress and impact indicates that employing evidence-informed approaches is crucial in order to ensure impact and buy-in (2019 [51]). This can include undertaking expert reviews and inquiries first, and then adopting a gradual implementation model which is carefully evaluated at each stage $\left(2019_{[51]}\right)$. International policy experiences provide further insights [Read More]. 


\section{Where does Brazil stand on education funding?}

\section{Key strengths}

- Brazil already dedicates a large share of national wealth to education and has aimed to increase this further.

- System-level redistributive policies help reduce inequities within a decentralised funding regime.

\section{Key challenges}

- $\quad$ Reorienting spending to strengthen provision in earlier levels, where inequalities take root and returns are highest.

- Promoting more efficient spending practices by combining outcome indicators, input targets and better monitoring.

- Committing to evidence-informed approaches to funding reform to enhance equity and efficiency in higher education

\section{Policy efforts in Brazil to move forward}

Since 2007, Fundeb has formed the core of ECEC, school and EJA funding. Each state and municipality must contribute $20 \%$ of specified revenue streams to a state-managed education fund; federal government matches $10 \%$ of the total, redistributing this to those states not reaching a national minimum for per-student spending, weighted by education level, type of institution and other indicators. Brazil approved a New Fundeb (2020[98]) (Novo Fundeb), making it permanent, more redistributive and increasing the federal contribution to $12 \%$ in 2021 , and $23 \%$ by 2026 . Until 2020 , Fundeb's federal complementary contribution was going to the poorest states, but funding inequalities between educational systems at municipality level remained. The New Fundeb directs the federal complementary contribution to the poorest municipalities, regardless of state-level context. In practice, rich municipal school systems in poor states will no longer receive the federal complementary contribution, while poor municipal school systems in rich states will, and will thus be able to increase the amount of resources per student. It is estimated that the new criteria will provide more resources to $46 \%$ of the municipalities that are underfunded (2019 $\left.{ }_{[99]}\right)$. New Fundeb sees 10 percentage points allocated to the poorest states, 10.5 percentage points to subnational public networks not reaching the minimum threshold, and a further 2.5 percentage points according to certain performance indicators (to be determined) such as enrolment rates, student performance and curricular alignment. Previous evaluations of Fundeb had found numerous positive impacts, including alleviation (but not eradication) of spending disparities (2018[100]), reduced age-grade distortion and improved enrolment, particularly for disadvantaged students (2018[101]). By changing the design of intergovernmental transfers, New Fundeb aims to address some identified weaknesses. In the future, continuing this process of monitoring, evaluating and then adjusting the policy will be important to ensure that Fundeb can continue to further reduce inequalities. As part of implementation efforts, MEC and FNDE have also produced guidelines to help subnational actors to understand the main changes and their role in the new arrangement (2021 ${ }_{[102])}$.

In 2018, Brazil updated the Student Financing Fund (Fundo de Financiamento Estudantil, FIES, 2001), which provides financial loans to students studying in private HEls. The New FIES (2018[103]) (Novo FIES) better targets loans, introducing graduated repayment schemes according to socio-economic status. In 2018 , around $30 \%$ of loans were earmarked for students with a family income of less than three times the minimum wage, on a zero-interest basis. With resources from regional development funds, the rest were earmarked for students with a family income less than five times the minimum wage, differentiated according to specific income levels. In 2020, eligibility was extended by lifting the requirement to have recently passed the ENEM. In a further new initiative, graduates would only start repaying loans once earning and at a proportional rate to their income. MEC also introduced the Student Financing Fund Management Committee bringing together representatives from MEC, and the ministries of Finance and Planning to improve strategic planning. Complementing FIES, ProUni (2004) offers scholarships for students from disadvantaged backgrounds and provides tax exemptions to private HEls offering free or reduced fees to students from low-income families, or who attended public upper secondary schools. Those programmes helped to increase the access to tertiary education in Brazil, mainly among 18-24 years-olds. However, analysis of international policy trends in this area indicates that while reducing financial barriers is important, increasing career guidance so students can make well-informed decisions about their orientation and career is also necessary (2018[16]). This is also key to enhancing education responsiveness and resilience (forthcoming $[27]$ ).

Although among many OECD education systems it has been more common for performance-based funding initiatives to be introduced in higher education $\left(2019_{[51]}\right)$, in Brazil, state-level initiatives to introduce performance-based funding allocations to municipalities for school funding have been extremely impactful. At least partly thanks to such measures, Ceará has become the highestperforming state in primary and lower secondary schooling when considering socio-economic context, while maintaining relatively low expenditure. In 2007 , the state introduced new indicators for intergovernmental transfers related to educational $(72 \%)$, health $(20 \%)$ and environmental $(8 \%)$ quality. Strengths of the initiative include having performance- and improvement-focused indicators to ensure that progress is a priority for all administrations and benefitting the lowest-performing (often the poorest) from the start (2020[104]). Aligning indicators to a state-wide policy priority for literacy helped realise system-level goals; ensuring sufficient technical assistance to municipalities was also key. Control measures were introduced to inhibit efforts to game the system. Such strengths could inform other state or federal efforts to increase efficiency through performance-based measures (2020[85]). 


\section{ANNEX A: STRUCTURE OF BRAZIL'S EDUCATION SYSTEM}

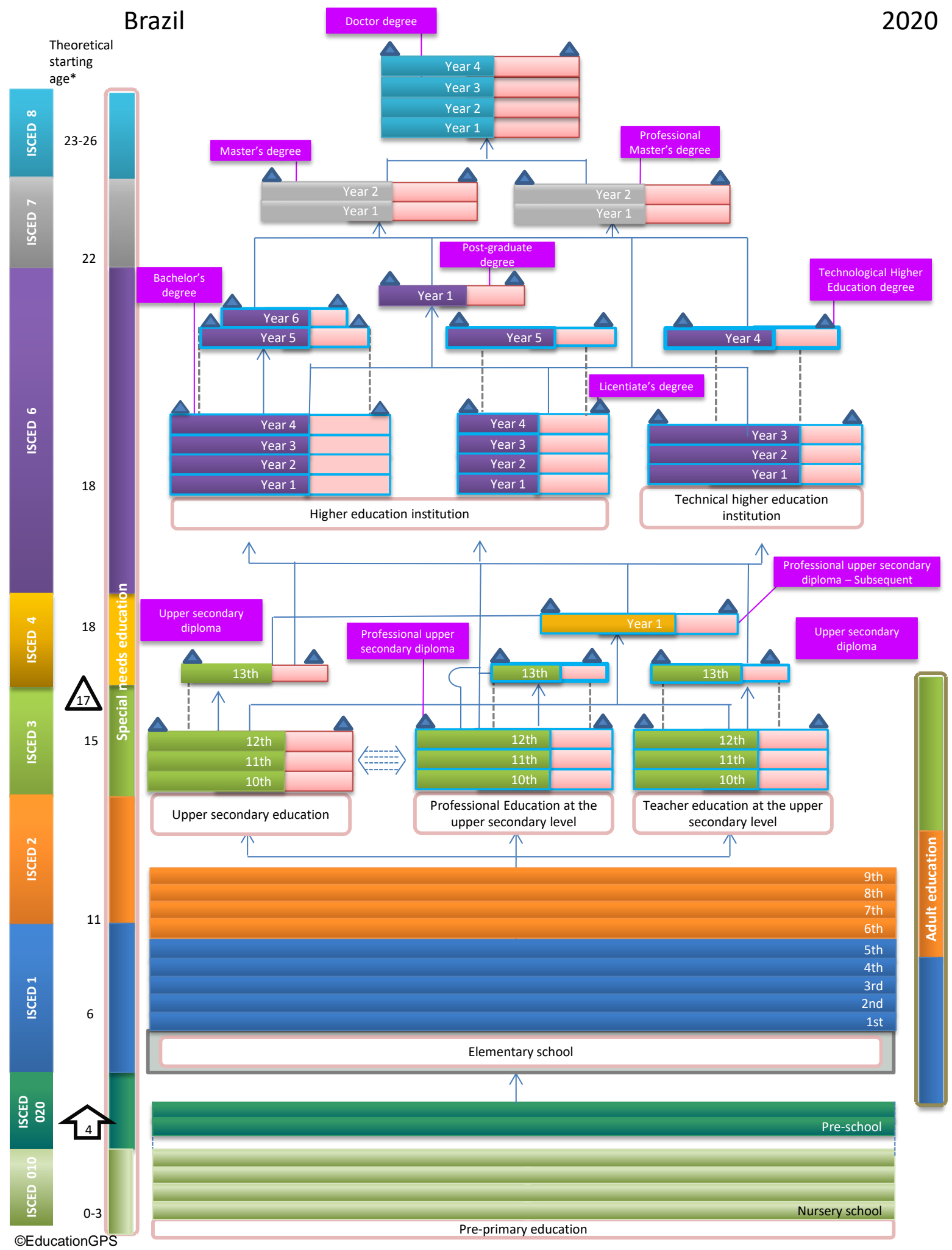

Note: The key for the interpretation of this table is available at the source link below.

Source: OECD (2020[108]), "Brazil: Overview of the Education System", OECD Education GPS, https://gpseducation.oecd.org/Content/MapOfEducationSystem/BRA/BRA 2011 EN.pdf (accessed on 20 May 2021). 


\section{ANNEX B: STATISTICS}

\begin{tabular}{|c|c|c|c|c|c|}
\hline \multicolumn{2}{|r|}{ List of key indicators ${ }^{1,2}$} & Brazil & $\begin{array}{l}\text { Average } \\
\text { or total }\end{array}$ & $\begin{array}{l}\text { Min } \\
\text { OECD }\end{array}$ & $\begin{array}{l}\text { Max } \\
\text { OECD }\end{array}$ \\
\hline \multicolumn{6}{|c|}{ Background information (OECD Statistics) } \\
\hline 1 & GDP per capita in equivalent USD converted using PPPs, $2019^{6}$ & 15689 & 46376 & 16077 & 120670 \\
\hline 2 & GDP grow th, 2017 & $1.3 \%$ & $2.7 \%$ & $1.2 \%$ & $9.1 \%$ \\
\hline 3 & Population density, inhab/km², 2018 & 25 & 38 & 3 & 519 \\
\hline 4 & Population aged less than 15 as a share of total population, 2018 & $21.4 \%$ & $17.7 \%$ & $12.2 \%$ & $28.4 \%$ \\
\hline 5 & Foreign-born population as a share of total population, 2018 & $\mathrm{~m}$ & $14.2 \%$ & $0.9 \%$ & $46.5 \%$ \\
\hline \multicolumn{6}{|c|}{$\begin{array}{ll}\text { Education outcomes } \\
\end{array}$} \\
\hline 6 & Mean performance in reading (PISA 2018) & 413 & 487 & 412 & 523 \\
\hline \multirow{3}{*}{7} & Average three-year trend in reading performance (PISA 2018) ${ }^{3,4}$ & 2.6 & 0.4 & -4.9 & 7.1 \\
\hline & Average three-year trend in mathematics performance (PISA 2018) ${ }^{3,4}$ & 4.6 & -0.6 & -9.1 & 6.4 \\
\hline & Average three-year trend in science performance (PISA 2018) & 2.2 & -1.9 & -10.7 & 6.4 \\
\hline 8 & $\begin{array}{l}\text { Share of 3-year-olds enrolled in early childhood education and care, } \\
2018 \text { (EAG 2020) }\end{array}$ & $65.3 \%$ & $78.1 \%$ & $2.5 \%$ & $100 \%$ \\
\hline \multirow{4}{*}{9} & \multicolumn{5}{|l|}{ Educational attainment among 25-34 year-olds, 2019 (EAG 2020) $^{7}$} \\
\hline & At least upper secondary education & $67.5 \%$ & $85.0 \%$ & $51.3 \%$ & $97.8 \%$ \\
\hline & Tertiary education & $21.3 \%$ & $45.0 \%$ & $23.6 \%$ & $70.0 \%$ \\
\hline & Vocational upper-secondary or post-secondary non-tertiary education & a & $25.8 \%$ & $1.6 \%$ & $47.1 \%$ \\
\hline \multirow{4}{*}{10} & \multicolumn{5}{|c|}{ 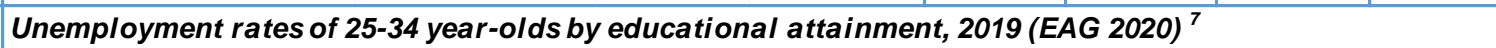 } \\
\hline & \begin{tabular}{|l|l|} 
Below upper secondary & \\
\end{tabular} & $14.5 \%$ & $13.2 \%$ & $3.3 \%$ & $36.9 \%$ \\
\hline & Upper secondary and post-secondary non-tertiary & $12.8 \%$ & $7.2 \%$ & $2.2 \%$ & $25.5 \%$ \\
\hline & Tertiary education & $7.6 \%$ & $5.4 \%$ & $1.4 \%$ & $19.5 \%$ \\
\hline & Students & & & & \\
\hline \multicolumn{6}{|c|}{ Policy lever 1: Equity and quality } \\
\hline 11 & First age of selection in the education system (PISA 2018) & 15 & 14 & 10 & 16 \\
\hline \multirow{2}{*}{12} & Share of students performing below Level 2 in reading (PISA 2018) & $50.0 \%$ & $22.6 \%$ & $11.1 \%$ & $49.9 \%$ \\
\hline & Share of students performing at Level 5 or above in reading (PISA 2018) & $1.8 \%$ & $8.7 \%$ & $0.9 \%$ & $15.0 \%$ \\
\hline \multirow{2}{*}{13} & $\begin{array}{l}\text { Isolation index in schools for high-achieving students in reading as } \\
\text { compared to all other students (PISA 2018) }\end{array}$ & 0.30 & 0.21 & 0.07 & 0.39 \\
\hline & $\begin{array}{l}\text { Isolation index in schools for socio-economically disadvantaged } \\
\text { students as compared to all other students (PISA 2018) }\end{array}$ & 0.24 & 0.17 & 0.09 & 0.27 \\
\hline 14 & $\begin{array}{l}\text { Share of students reporting having repeated at least a grade in primary, } \\
\text { low er secondary or upper secondary education (PISA 2018) }\end{array}$ & 34.1 & 11.4 & 0.9 & 40.8 \\
\hline 15 & $\begin{array}{l}\text { Share of variance in reading performance in PISA explained by the } \\
\text { index of economic, social and cultural status (PISA 2018) }\end{array}$ & $14.0 \%$ & $12.0 \%$ & $6.2 \%$ & $19.1 \%$ \\
\hline 16 & Score difference betw een girls and boys in reading (PISA 2018) ${ }^{3}$ & 25.7 & 29.7 & 10.3 & 51.5 \\
\hline \multicolumn{6}{|c|}{ Policy lever 2: Preparing students for the future } \\
\hline 17 & $\begin{array}{l}\text { Adjusted mean proficiency in literacy among } 16-64 \text { year-olds on a scale } \\
\text { of } 500 \text { (Survey of Adult Skills, PIAAC, 2012) }\end{array}$ & NP & 267.7 & 220.1 & 296.2 \\
\hline 18 & $\begin{array}{l}\text { Difference in literacy scores betw een youngest (25-34) and oldest (55- } \\
65 \text { ) adults (Survey of Adult Skills, PIAAC, 2012) }\end{array}$ & NP & 15.6 & -8.3 & 37.6 \\
\hline \multirow{4}{*}{19} & \multicolumn{5}{|c|}{ Share of students in upper secondary education, by programme orientation, in 2018 (EAG 2020) } \\
\hline & General programmes & $89.5 \%$ & $58.1 \%$ & $28.4 \%$ & $91.3 \%$ \\
\hline & Vocational programmes & $10.5 \%$ & $41.9 \%$ & $8.7 \%$ & $71.6 \%$ \\
\hline & Vocational programmes w hich are combined school and w ork-based & a & $34.4 \%$ & $2.8 \%$ & $100.0 \%$ \\
\hline 20 & $\begin{array}{l}\text { First-time graduation rates from tertiary education for students below } \\
\text { the age of } 30 \text {, excluding international students, } 2018 \text { (EAG 2020) }\end{array}$ & $\mathrm{m}$ & $37.6 \%$ & $8.1 \%$ & $67.4 \%$ \\
\hline 21 & $\begin{array}{l}\text { Share of } 18-24 \text { year-olds not in education, employment or training, } 2019 \\
(\text { EAG 2020) }\end{array}$ & $30.6 \%$ & $14.3 \%$ & $6.1 \%$ & $32.2 \%$ \\
\hline
\end{tabular}




\begin{tabular}{|c|c|c|c|c|c|}
\hline \multicolumn{2}{|r|}{ List of key indicators } & Brazil & $\begin{array}{l}\text { Average } \\
\text { or total }\end{array}$ & $\begin{array}{l}\text { Min } \\
\text { OECD }\end{array}$ & $\begin{array}{l}\text { Max } \\
\text { OECD }\end{array}$ \\
\hline \multicolumn{6}{|c|}{ Institutions } \\
\hline \multicolumn{6}{|c|}{ Policy lever 3: School improvement } \\
\hline \multirow{3}{*}{22} & \multicolumn{5}{|l|}{ The learning environment (PISA 2018) } \\
\hline & Mean index of teacher support in language-of-instruction lessons & 0.43 & 0.01 & -0.61 & 0.47 \\
\hline & Mean index of students' sense of belonging & -0.19 & 0.00 & -0.28 & 0.46 \\
\hline 23 & $\begin{array}{l}\text { Share of principals reporting that teachers have the necessary skills to } \\
\text { integrate digital devices in instruction }\end{array}$ & 50.63 & 64.63 & 27.26 & 84.14 \\
\hline \multirow{3}{*}{24} & \multicolumn{5}{|c|}{ Share of principals reporting that the types of engagement occur "quite a bit" or "a lot" (TALIS 2018) } \\
\hline & Parental/guardian involvement in school activities & $59.8 \%$ & $47.9 \%$ & $22.5 \%$ & $89.2 \%$ \\
\hline & School co-operation w ith the local community & $91.6 \%$ & $71.6 \%$ & $28.1 \%$ & $97.8 \%$ \\
\hline 25 & $\begin{array}{l}\text { Average class size in low er secondary public schools, } 2018 \text { (EAG } \\
\text { 2020) }\end{array}$ & 28 & 23 & 16 & 35 \\
\hline 26 & $\begin{array}{l}\text { Ratio of actual teachers' salaries to earnings for full-time, full-year adult } \\
\text { w orkers w ith tertiary education, in low er secondary education, general } \\
\text { programmes, } 2019 \text { (EAG 2020) }\end{array}$ & $\mathrm{m}$ & 0.89 & 0.65 & 1.44 \\
\hline 27 & $\begin{array}{l}\text { Share of teachers } w \text { ho believe the teaching profession is valued in } \\
\text { society (TALIS 2018) }\end{array}$ & $11.4 \%$ & $25.8 \%$ & $4.5 \%$ & $67.0 \%$ \\
\hline \multicolumn{6}{|c|}{ Policy lever 4: Evaluation and assessment to improve student outcomes } \\
\hline \multirow{3}{*}{28} & \multicolumn{5}{|c|}{$\begin{array}{l}\text { Share of students in schools where the following arrangements aimed at quality assurance and } \\
\text { improvement are used, either mandatorily or on the schools' initiative (PISA 2018) }\end{array}$} \\
\hline & Internal/Self-evaluation & $96.1 \%$ & $94.7 \%$ & $46.1 \%$ & $100.0 \%$ \\
\hline & External evaluation & $87.7 \%$ & $76.9 \%$ & $8.5 \%$ & $100.0 \%$ \\
\hline 29 & Mean index of perceived teacher feedback (PISA 2018) & -0.16 & 0.01 & -0.41 & 0.53 \\
\hline 30 & $\begin{array}{l}\text { Share of low er secondary teachers w hose school principals report } \\
\text { formally appraising their teachers at least once a year (TALIS 2018) }\end{array}$ & $77.5 \%$ & $63.5 \%$ & $11.3 \%$ & $98.1 \%$ \\
\hline \multicolumn{6}{|c|}{ Systems } \\
\hline \multicolumn{6}{|c|}{ Policy lever 6: Funding } \\
\hline 31 & $\begin{array}{l}\text { Public expenditure on primary to tertiary institutions as a share of GDP, } \\
2017 \text { (EAG 2020) }\end{array}$ & $5.1 \%$ & $4.1 \%$ & $2.9 \%$ & $6.4 \%$ \\
\hline \multirow{6}{*}{32} & \multicolumn{5}{|c|}{$\begin{array}{l}\text { Annual expenditure per student by educational institutions in equivalent USD converted using PPPs for } \\
\text { GDP, } 2017\end{array}$} \\
\hline & Pre-primary education & $\mathrm{m}$ & 9079 & 1556 & 19326 \\
\hline & Primary education & $\mathrm{m}$ & 9090 & 2782 & 19690 \\
\hline & Low er secondary education & $\mathrm{m}$ & 10527 & 2438 & 23073 \\
\hline & Upper secondary education & $\mathrm{m}$ & 10888 & 3418 & 22427 \\
\hline & Tertiary education & $\mathrm{m}$ & 16327 & 2335 & 52089 \\
\hline \multirow{3}{*}{33} & \multicolumn{5}{|c|}{ Relative proportions of expenditure on educational institutions (primary to tertiary) in 2017 (EAG 2020) } \\
\hline & Public sources & $\mathrm{m}$ & $83.0 \%$ & $62.6 \%$ & $98.0 \%$ \\
\hline & Private sources (including international sources) & $\mathrm{m}$ & $17.0 \%$ & $3.1 \%$ & $37.4 \%$ \\
\hline \multicolumn{6}{|c|}{$\begin{array}{l}\text { Notes: } \\
\text { 1. The average, total, minimums and maximums refer to OECD education systems except in the Survey of Adult Skills where they refer to participating countries. For } \\
\text { indicators } 6,12 \text { and } 15-16 \text { the average value refers to the arithmetic mean across all OECD M ember countries (and Colombia), excluding Spain. } \\
\text { 2. " } m \text { " is included when data is not available; "NP" is included if the country is not participating in the study; "a": included when the category is not applicable. } \\
\text { 3. Statistically significant values are shown in bold (PISA only). } \\
\text { 4. The average three year trend is the average change in PISA score points from a country's/economy's earliest participation to PISA } 2018 . \\
\text { 5. The isolation indices range from } 0 \text { to } 1 \text {, with } 0 \text { corresponding to no segregation and } 1 \text { to full segregation. } \\
\text { 6. For Brazil, the value is estimated. } \\
\text { 7. For Brazil, the reference year is } 2018 \text {. } \\
\text { 8. Public expenditure refers to final funds, after transfers between public and private sectors. }\end{array}$} \\
\hline
\end{tabular}




\section{REFERENCES}

Abuchaim, B. (2018), Panorama das Políticas de Educação Infantil no Brasil [Overview of Early Childhood Education Policies in Brazil], UNESCO Brazil, https://unesdoc.unesco.org/ark:/48223/pf0000261453 (accessed on 27 February 2021).

Alferes, M. and J. Mainardes (2019), "O Pacto Nacional pela Alfabetização [The National Pact for Literacy at the Right Age in action: literature review]", Ensaio, Vol. 27/102, http://dx.doi.org/10.1590/s0104-40362018002601262. (accessed on 8 June 2021).

Almeida Prado, M. (2019), Planos de Carreira de Professores dos Estados e do Distrito Federal em Perspectiva Comparada [A Comparative Perspective of Career Plans for State and Federal District Teachers], INEP, Brasília, http://inep.gov.br/informacao-dapublicacao/-/asset publisher/6JYIsGMAMkW1/document/id/6693068 (accessed on 2 March 2021).

Associação dos Municípios da Região da Grande Florianópolis, (2021), "Prefeitos assinam termo de adesão ao ADE Granfpolis" [Mayors sign term of adhesion to ADE Granfpolis], https://granfpolis.org.br/noticias/ver/2021/03/prefeitos-assinam-termo-de-adesao-ao-adegranfpolis (accessed on 8 June 2021).

Bertoni, E. et al. (2018), School Finance in Latin America - A Conceptual Framework, InterAmerican Development Bank, Washington D.C., https://publications.iadb.org/publications/english/document/School-Finance-in-LatinAmerica-A-Conceptual-Framework-and-a-Review-of-Policies.pdf (accessed on 27 February 2021).

Centre for Public Impact (2020), A política de Educação em Tempo Integral no Estado brasileiro de Pernambuco [The policy of Full-Time Education in the Brazilian State of Pernambuco], https://www.institutonatura.org/wp-content/uploads/2020/08/Apoli\%CC\%81tica-de-Educac\%CC\%A7a\%CC\%83o-em-Tempo-Integral-no-Estadobrasileiro-de-Pernambuco..pdf.

Cruz, G. and R. Rocha (2018), "Efeitos do FUNDEF/B sobre Frequência Escolar, Fluxo Escolar e Trabalho Infantil: Uma Análise com Base nos Censos de 2000 e 2010", Estudos Econômicos (São Paulo), Vol. 48/1, pp. 39-75, http://dx.doi.org/10.1590/0101$\underline{4161481239 \mathrm{gcr}}$.

Cruz, P. et al. (2016), Media Center: Innovating with Distance Learning in Amazonas, Brazil, https://www.brookings.edu/wp-content/uploads/2016/07/FINAL-Media-Center-CaseStudy.pdf (accessed on 8 June 2021).

Fernandes dos Santos, A. and M. Ferreira (2020), "Base Nacional Comum Curricular, Qualidade da Educação e Autonomia Docente [National Common Core Curriculum, Educational Quality and Teachers' Autonomy]", Em Aberto, Vol. 33/107, http://portal.inep.gov.br/informacao-da-publicacao/lasset publisher/6JYIsGMAMkW1/document/id/6949770 (accessed on 8 June 2021). 
Fernandes, J. and J. Nogueira (2020), "Plano de Ações Articuladas: Melhoria da Educação e Redução das Desigualdades [Articulated Action Plan: Improving Education and Reducing Inequalities]", in Mello, J. (ed.), Implementação de Políticas e Atuação de Gestores Públicos: Experiências Recentes das Políticas de Redução das Desigualdades [Policy Implementation and Performance of Public Managers: Recent Experiences from Policies to Reduce Inequalities], IPEA, Brasilia, http://repositorio.ipea.gov.br/handle/11058/9862 (accessed on 26 February 2021).

Ferraz Leal, T. and A. Gomes de Morais (2020), "Avaliação da Alfabetização e Formação de Professores Alfabetizadores no Brasil: Caminhos e Descaminhos [Literacy Assessment and Training of Literacy Teachers in Brazil: Progression and Regression]", 33, No. 108, Em Aberto, Brasília, http://emaberto.inep.gov.br/ojs3/index.php/emaberto/article/view/4276/3811 (accessed on 1 March 2021).

Franzese, C. and R. Pacheco (2019), Consórcios públicos: estratégias e mecanismos de gestão para a continuidade das políticas públicas, Itaú Social, https://www.itausocial.org.br/wpcontent/uploads/2018/06/Cons\%C3\%B3rcios vers\%C3\%A3o-resumida.pdf (accessed on 9 June 2021).

Fundação Itaú Social (2015), Relatório de Avaliação Econômica e Estudos Qualitativos: O Programa Mais Educação [Economic Evaluation Report and Qualitative Studies: The More Education Program], https://ptdocz.com/doc/803034/ (accessed on 16 April 2021).

Gouëdard, P. et al. (2020), "Curriculum reform: A literature review to support effective implementation", OECD Education Working Papers, No. 239, OECD Publishing, Paris, https://dx.doi.org/10.1787/efe8a48c-en (accessed on 2 March 2021).

Governador do Estado do Rio Grande Do Sul (2012), Lei N.o 14.030, de 26 de junho de 2012 [Law No. 14.030, 26 June 2012], Assembleia Legislativa, Porto Alegre, http://www.al.rs.gov.br/filerepository/repLegis/arquivos/14.030.pdf (accessed on 2 March 2021).

IBGE (2019), Perfil dos Municípios Brasileiros 2018 [Profile of Brazilian Municipalities 2018]], IBGE, Rio de Janeiro, https://biblioteca.ibge.gov.br/visualizacao/livros/liv101668.pdf (accessed on 2 March 2021).

IBGE (2019), Síntese de Indicadores Sociais: Uma Análise das Condições de Vida da População Brasileira 2018 [Synthesis of Social Indicators: An Analysis of the Living Conditions of the Brazilian Population 2018], IBGE, Brasília.

IBGE (n.d.), Pesquisa Nacional de Saúde do Escolar - PeNSE [National School health Survey - PeNSE]], website of IBGE, https://www.ibge.gov.br/estatisticas/sociais/populacao/9134pesquisa-nacional-de-saude-do-escolar.html?t=0-que-e (accessed on 8 March 2021).

INEP (2020), Relatório do 30 Ciclo de Monitoramento das Metas do Plano Nacional de Educação [Report on the 3rd Monitoring Cycle of the National Education Plan].

INEP (2019), Censo da Educação Superior 2018: Notas Estatísticas [Higher Education Census 2018: Statistical Notes], INEP, Brasília.

INEP (2019), Censo da Educação Superior 2019: Divulgação dos Resultados [Higher Education Census 2019: Dissemination of Results], INEP, Brasília. 
INEP (2018), Relações entre Avaliação e Gestão Educacional em Municípios Brasileiros: Estudo em Dez Municípios da Federação - Relatório Final de Pesquisa (Volume II) [Relationships between Evaluation and Educational Management in Brazilian Municipalities: Study of Ten Municipalities - Final Research Report (Volume II)].

Instituto TIM (n.d.), Busca Ativa Escolar [School Active Search], https://institutotim.org.br/en/projects/busca-ativa-escolar/ (accessed on 16 April 2021).

Instituto Unibanco (2020), Análise dos Processos de Implementação do Novo Ensino Médio em Estados Brasileiros: Ficha Técnica (Analysis of the implementation processes of the New High School in Brazilian States: Technical File), https://www.researchgate.net/publication/349952633 Analise dos processos de implem entacao do Novo Ensino Medio em estados brasileiros marco de 2020 (accessed on 27 April 2021).

Interdisciplinaridade e Evidências no Debate Educacional (2020), O que os dados do IDEB 2019 dizem sobre a aprendizagem dos alunos? [What do IDEB 2019 data say about student learning?], https://www.portaliede.com.br/o-que-os-dados-do-ideb-2019-dizemsobre-a-aprendizagem-dos-alunos/ (accessed on 16 April 2021).

Laboratório de Estudos e Pesquisas em Economia Social (2020), Desenvolvimento do [79] Sistema de monitoramento da Educação Infantil de Boa Vista [Development of the Monitoring System for Early Childhood Education in Boa Vista], http://lepes.fearp.usp.br/desenvolvimento-do-sistema-de-monitoramento-da-educacaoinfantil-de-boa-vista/ (accessed on 16 April 2021).

Loureiro, A. et al. (2020), The State of Ceará in Brazil is a Role Model for Reducing Learning Poverty, World Bank, Washington D.C., http://documents1.worldbank.org/curated/en/281071593675958517/pdf/The-State-ofCeara-in-Brazil-is-a-Role-Model-for-Reducing-Learning-Poverty.pdf (accessed on 26 February 2021).

Martins, C. and M. Mattos Barreto (2017), "Public policy early childhood education in Brazil: the implementation of Proinfancia", Revista Sapiência: Sociedade, Saberes e Práticas Educacionais, Vol. 6/1.

MEC (2021), Catálogo Nacional de Cursos Técnicos: 4a edição [National Catalogue of Technical Courses: 4th edition], MEC, Brasília, http://cnct.mec.gov.br/cnct-api/catalogopdf (accessed on 5 March 2021).

MEC (2021), Matriz Nacional Comum de Competências do Diretor Escolar - Proposta [Common National Matrix of Competences for the School Director - Proposal], MEC, Brasília.

MEC (2020), "Bem-vindo ao programa Tempo de Aprender!" [Welcome to the Time to Learn Progrmme"], http://alfabetizacao.mec.gov.br/tempo-de-aprender (accessed on 12 May 2021).

MEC (2020), "Conheça o programa" ["About the programme"], Novos Caminhos (New Pathways ), website of MEC, http://portal.mec.gov.br/novoscaminhos/?pagina=estrategias (accessed on 5 March 2021).

MEC (2020), "Parceria entre Cidadania e MEC vai estimular o desenvolvimento infantil" ["Partnership between Citizenship and MEC will stimulate child development"], website of MEC, https://www.gov.br/pt-br/noticias/educacao-e-pesquisa/2020/08/parceria-entrecidadania-e-mec-vai-estimular-o-desenvolvimento-infantil (accessed on 1 March 2021). 
MEC (2020), Perguntas e respostas sobre o Clique Escola [Questions and answers about Clique Escola], https://www.gov.br/mec/pt-br/assuntos/noticias/perguntas-e-respostassobre-o-clique-escola (accessed on 16 April 2021).

MEC (2020), Portaria № 407, de 6 de julho de 2020 [Ordinance No. 407, 06 July, 2020], MEC, Brasília, https://www.in.gov.br/en/web/dou/-/portaria-n-407-de-6-de-julho-de-2020$\underline{265460371}$ (accessed on 5 March 2021).

MEC (2020), Portaria № 421, de 23 de Abril de 2020 [Ordinance No. 421, 23 Abril 2020], Diário Oficial da União, Brasília.

MEC (2020), Portaria № 62, de 24 de janeiro de 2020 [Ordinance No. 62, 24 January, 2020], MEC, Brasília, https://www.in.gov.br/en/web/dou/-/portaria-n-62-de-24-de-janeiro-de-2020239866490 (accessed on 5 March 2021).

MEC (2020), Sistema Ideb por Escola já está disponível [Ideb by School System is now available], https://www.gov.br/inep/pt-br/assuntos/noticias/ideb/sistema-ideb-por-escola-jaesta-disponivel (accessed on 16 April 2021).

MEC (2019), Política Nacional de Alfabetização [National Literacy Policy], MEC, Brasília, http://alfabetizacao.mec.gov.br/images/pdf/caderdo final pna.pdf (accessed on 23 February 2021).

MEC (2019), Portaria № 1.718, de 08 de outubro de 2019 [Ordinance No. 1,718, OF 08 October, 2019], MEC, Brasília, https://www.in.gov.br/en/web/dou/-/portaria-n-1.718-de-8de-outubro-de-2019-220789583 (accessed on 5 March 2021).

MEC (2019), Portaria № 2.116, de 6 de dezembro de 2019 [Ordinance No. 2,116 of 06 December 2019], Diário Oficial da União, https://www.in.gov.br/en/web/dou/-/portaria-n2.116-de-6-de-dezembro-de-2019-232132483 (accessed on 16 April 2021).

MEC (2018), Base Nacional Comun Curricular [National Common Core Curriculum], http://basenacionalcomum.mec.gov.br/images/BNCC El EF 110518 versaofinal site.pdf (accessed on 26 February 2021).

MEC (2018), Parâmetros Nacionais de Qualidade da Educação Infantil [National Quality Parameters of Early Childhood Education], MEC, Brasília, http://portal.mec.gov.br/docman/2020/141451-public-mec-web-isbn-2019-003/file (accessed on 3 March 2021).

MEC (2018), Portaria № 209, de 7 de março de 2018 [Ordinance No. 209 of 07 March 2018]], Diario Oficial da Uniao, https://www.in.gov.br/materia/lasset publisher/Kujrw0TZC2Mb/content/id/5744626/do1-2018-03-08-portaria-n-209-de-7de-marco-de-2018-5744622 (accessed on 26 February 2021).

MEC (2018), Portaria № 649, de 10 de julho de 2018 [Ordinance No. 649 of 10 July 2018 ], https://www.in.gov.br/materia/-/asset publisher/Kujrw0TZC2Mb/content/id/29495231/do12018-07-11-portaria-n-649-de-10-de-julho-de-2018-29495216.

MEC (2016), Portaria № 1.145, de 10 de Outubro de 2016 [Ordinance No. 1,145, of October 10, 2016], https://www.in.gov.br/web/dou/-/portaria-n-1-145-de-10-de-outubro-de-201622055471-22055471. 
NO. 38 - EDUCATION POLICY OUTLOOK IN BRAZIL - WITH A FOCUS ON NATIONAL AND SUBNATIONAL POLICIES | 32

MEC (2009), Indicadores da Qualidade na Educação Infantil [Quality Indicators in Early Childhood Education], MEC, Brasília, https://www.unicef.org/brazil/media/506/file/Indicadores da Qualidade na Educacao Infa ntil.pdf (accessed on 3 March 2021).

MEC and FNDE (2021), Novo Fundeb [New Fundeb], https://www.gov.br/fnde/pt-br/acesso-ainformacao/acoes-e-programas/financiamento/fundeb/CartilhaNovoFundeb2021.pdf (accessed on 20 April 2021).

MEC/CNE (2021), Resolução CNE/CP № 1, de 05 de janeiro de 2021 [CNE/CP Resolution No. 1, 05 January, 2021], MEC/CNE, Brasília, https://www.in.gov.br/en/web/dou//resolucao-cne/cp-n-1-de-5-de-janeiro-de-2021-297767578 (accessed on 5 March 2021).

MEC/CNE (2020), Resolução CNE/CP № 1, de 27 De Outubro de 2020 [CNE / CP Resolution No. 1, of October 27, 2020], CNE, Brasília, https://www.in.gov.br/en/web/dou/-/resolucaocne/cp-n-1-de-27-de-outubro-de-2020-285609724 (accessed on 2 March 2021).

MEC/CNE (2019), Resolução CNE/CP № 2, de 20 de Dezembro de 2019 [CNE / CP $[58]$ Resolution No. 2, of December 20, 2019], CNE, Brasília, http://portal.mec.gov.br/index.php?option=com docman\&view=download\&alias=135951rcp002-19\&category slug=dezembro-2019-pdf\&ltemid=30192 (accessed on 2 March 2021).

MEC/CNE (2012), Resolução № 1, de 23 de Janeiro 2012 [Resolution No. 1, 23 January, 2012], MEC, Brasilia, http://portal.mec.gov.br/index.php?option=com docman\&view=download\&alias=9816rceb001-12\&ltemid=30192 (accessed on 26 February 2021).

Moraes, G., A. de Albuquerque and R. dos Santos (2020), Avaliação da Educação Profissional e Tecnológica: Um Campo em Construção [Evaluation of Professional and Technological Education: A Field under Construction], INEP, Brasília, http://portal.inep.gov.br/informacao-da-publicacao/lasset publisher/6JYIsGMAMkW1/document/id/6989228 (accessed on 1 March 2021).

Movimento Pela Base (2021), Movimento Pela Base - Início [Movement for a Core Curriculum - Home], https://movimentopelabase.org.br/.

OECD (2021), "Core Considerations for Brazil: Managing Change in a Complex National Assessment System", OECD Education Policy Perspectives, OECD Publishing, Paris.

OECD (2021), Education in Brazil: An International Perspective, OECD Publishing, Paris, https://dx.doi.org/10.1787/60a667f7-en.

OECD (2021), Education Policy Outlook: Brazil - With a Focus on International Policies, OECD Publishing, https://www.oecd.org/education/policy-outlook/country-profile-Brazil2021-INT-EN.pdf.

OECD (2020), Auditing Decentralised Policies in Brazil: Collaborative and Evidence-Based Approaches for Better Outcomes, OECD Public Governance Reviews, OECD Publishing, Paris, https://dx.doi.org/10.1787/30023307-en.

OECD (2020), "Brazil: Overview of the Education System", OECD Education GPS, https://gpseducation.oecd.org/Content/MapOfEducationSystem/BRA/BRA 2011 EN.pdf (accessed on 12 March 2021). 
33 | NO. 38 - EDUCATION POLICY OUTLOOK IN BRAZIL - WITH A FOCUS ON NATIONAL AND SUBNATIONAL POLICIES

OECD (2020), Education at a Glance 2020: OECD Indicators, OECD Publishing, Paris, https://dx.doi.org/10.1787/69096873-en.

OECD (2020), Going Digital in Brazil, OECD Reviews of Digital Transformation, OECD Publishing, Paris, https://dx.doi.org/10.1787/e9bf7f8a-en.

OECD (2020), Lessons for Education from COVID-19: A Policy Maker's Handbook for More Resilient Systems, OECD Publishing, Paris, https://dx.doi.org/10.1787/0a530888-en.

OECD (2020), OECD Economic Surveys: Brazil 2020, OECD Publishing, Paris, https://dx.doi.org/10.1787/250240ad-en.

OECD (2020), PISA 2018 Results (Volume V): Effective Policies, Successful Schools, PISA, OECD Publishing, Paris, https://dx.doi.org/10.1787/ca768d40-en.

OECD (2020), TALIS 2018 Results (Volume II): Teachers and School Leaders as Valued Professionals, TALIS, OECD Publishing, Paris, https://dx.doi.org/10.1787/19cf08df-en.

OECD (2020), "The impact of COVID-19 on student equity and inclusion: supporting vulnerable students during school closures and school re-openings", OECD Policy Responses to Coronavirus (COVID-19).

OECD (2019), Education Policy Outlook 2019: Working Together to Help Students Achieve their Potential, OECD Publishing, Paris, https://dx.doi.org/10.1787/2b8ad56e-en.

OECD (2019), PISA 2018 Results (Volume I): What Students Know and Can Do, PISA, OECD Publishing, Paris, https://dx.doi.org/10.1787/5f07c754-en.

OECD (2019), PISA 2018 Results (Volume II): Where All Students Can Succeed, PISA, OECD Publishing, Paris, https://dx.doi.org/10.1787/b5fd1b8f-en.

OECD (2019), PISA 2018 Results (Volume III): What School Life Means for Students' Lives, PISA, OECD Publishing, Paris, https://dx.doi.org/10.1787/acd78851-en.

OECD (2018), Education Policy Outlook 2018: Putting Student Learning at the Centre, OECD Publishing, Paris, https://dx.doi.org/10.1787/9789264301528-en.

OECD (2018), Getting Skills Right: Brazil, Getting Skills Right, OECD Publishing, Paris, https://dx.doi.org/10.1787/9789264309838-en.

OECD (2018), OECD Economic Surveys: Brazil 2018, OECD Publishing, Paris, https://dx.doi.org/10.1787/eco surveys-bra-2018-en.

OECD (2018), Rethinking Quality Assurance for Higher Education in Brazil, Reviews of National Policies for Education, OECD Publishing, Paris, https://dx.doi.org/10.1787/9789264309050-en.

OECD (2017), Economic Policy Reforms 2017: Going for Growth, OECD Publishing, Paris, https://dx.doi.org/10.1787/growth-2017-en.

OECD (2015), "Brazil policy brief: Education and skills - Developing skills and education for growth", OECD Better Policies Series, https://www.oecd.org/policy-briefs/brazil-developingskills-and-education-for-growth.pdf (accessed on 8 March 2021).

OECD (2015), Education Policy Outlook: Brazil, OECD Publishing, Paris, http://www.oecd.org/education/Brazil-country-profile.pdf (accessed on 8 March 2021). 
OECD (2014), Investing in Youth: Brazil, Investing in Youth, OECD Publishing, Paris, https://dx.doi.org/10.1787/9789264208988-en.

OECD (forthcoming), Education in Brazil: an International Perspective, OECD Publishing, Paris.

OECD (forthcoming), Education Policy Outlook 2021: Framework for Responsiveness and Resilience in Education Policy (working title), OECD Publications.

Presidência da República (2020), Emenda Constitucional № 108, de 26 de agosto de 2020 [Constitutional Amendment No. 108, 26 August 2020], Presidência da República, Brasilia, http://www.planalto.gov.br/ccivil 03/constituicao/emendas/emc/emc108.htm (accessed on 26 February 2021).

Presidência da República (2018), Estratégia Brasileira para a Transformação Digital [Brazilian Strategy for Digital Transformation], Presidência da República, Brasília.

Presidência da República (2016), Lei № 13.257, de 8 de março de 2016 [Law No. 13.257, 08 March 2016], Presidência da República, Brasilia, http://www.planalto.gov.br/ccivil 03/ Ato2015-2018/2016/Lei/L13257.htm (accessed on 26 February 2021).

Presidência da República (2014), Plano Nacional de Educação PNE 2014-2024: Linha De Base [National Education Plan PNE 2014-2024: Baseline], INEP, Brasília, http://pne.mec.gov.br/publicacoes/item/download/13 7101e1a36cda79f6c97341757dcc4d $\underline{04}$ (accessed on 2 March 2021).

Presidência da República (2012), Lei № 12.695, de 25 de julho de 2012 [Law No. 12.695, 25 July 2012], Presidência da República, Brasilia, http://www.planalto.gov.br/ccivil 03/ ato2011-2014/2012/lei/l12695.htm (accessed on 26 February 2021).

Rede Nacional Primeira Infância (2020), Plano Nacional pela Primeira Infância [National Plan for Early Childhood], http://primeirainfancia.org.br/wp-content/uploads/2020/10/PNPI.pdf (accessed on 26 February 2021).

República, P. (2017), Lei № 13.415, de 16 de Feveiro de 2017 [Law No. 13.415 of February 16, 2017], http://www.planalto.gov.br/ccivil 03/ ato2015-2018/2017/lei//13415.htm.

Santos, J. (2019), "O Financiamento da Educação Infantil a Partir da Implementação do

Fundeb: Avanços e Limites [The Financing of Children's Education from the Implementation of Fundeb: Advances and Limits]", Notandum, Vol. 22/50, http://periodicos.uem.br/ojs/index.php/notandum/article/view/46755/751375139707 (accessed on 26 February 2021).

Secretaria da Educação São Paulo (2019), Modernização da Carreira Docente [Modernisation of the Teaching Career], https://programas.educacao.sp.gov.br/documents/coletivacarreira-13-11-2019-v2.pdf (accessed on 16 April 2021).

Secretaria de Estado da Educação, Ciência e Tecnologia da Paraíba (2021), Currículos por competências e habilidades: Caminhos para a integração entre a formação básica e a educação profissional e técnica, Governo da Paraíba, https://sites.google.com/prod/see.pb.gov.br/pbeduca/eci/ecit-tecnica/publicacoes. 
Secretaria de Planejamento, G. (2019), Eficiência da Rede Estadual de Ensino no Rio Grande Do Sul: Análise Qualitativa Comparativa das Escolas Classificadas como Mais e Menos Eficientes [Efficiency of the State Education Network in Rio Grande Do Sul: Qualitative Comparative Analysis of Schools Classified as More and Less Efficient], Secretaria de Planejamento, Governança e Gestão, Rio Grande do Sul, https://planejamento.rs.gov.br/upload/arquivos/201901/24170219-relatorio-avaliacaoqualitativa-eficiencia-educacao.pdf (accessed on 3 March 2021).

Todos pela Educação (2021), 2º Relatório Anual de Acompanhamento do Educação Já! [2nd Annual Monitoring Report for Education Now!], Todos pela Educação, https://todospelaeducacao.org.br/wordpress/wp-content/uploads/2021/02/2o-RelatorioAnual-de-Acompanhamento-do-Educacao-Ja final.pdf (accessed on 26 February 2021).

Todos pela Educação (2021), "Execução Orçamentária do Ministério da Educação: Consolidado do Exercício de 2020 [Budget Execution of the Ministry of Education: Consolidated Financial Year 2020]", $6^{\circ}$ Relatorio Bimestral, Todos pela Educação, https://todospelaeducacao.org.br/wordpress/wp-content/uploads/2021/02/6\%C2\%B0Relatorio-Bimestral-da-Execucao-Orcamentaria-do-MEC.pdf (accessed on 26 February 2021).

Todos pela Educação (2020), Política Nacional de Valorização e Profissionalização do Ensino [National Policy for the Valuation and Professionalisation of Education], https://www.todospelaeducacao.org.br/ uploads/ posts/252.pdf (accessed on 16 April 2021).

Todos pela Educação (2020), Propostas para Aprimoramento nos Mecanismos de Financiamento da Educação Básica [Proposals for Improvement in Mechanisms for Financing of Basic education], Todos pela Educação, https://www.todospelaeducacao.org.br/ uploads/ posts/258.pdf (accessed on 26 February 2021).

Todos pela Educação (2019), Formação inicial de professores no Brasil [Initial teacher education in Brazil], https://www.todospelaeducacao.org.br/ uploads/ posts/317.pdf?1619510590 (accessed on 16 April 2021).

Todos pela Educação (2019), Nota Técnica: Análise da relação entre investimento por aluno e qualidade do ensino [Technical Note: Analysis of the relationship between investment per student and quality of education], https://www.todospelaeducacao.org.br/ uploads/ posts/319.pdf?477736800 (accessed on 16 April 2021).

Todos pela Educação (2016), Brasil Carinhoso [Kind Brazil], https://www.todospelaeducacao.org.br/primeirainfancia/pais brasil.html (accessed on 14 April 2021).

UNESCO, UNICEF, Brookings Institution \& World Bank (2017), Overview MELQO: Measuring Early Learning Quality and Outcomes, https://unesdoc.unesco.org/ark:/48223/pf0000248053/PDF/248053eng.pdf.multi (accessed on 16 April 2021).

UNICEF (2018), Panorama da Distorção Idade-Série no Brasil (Overview of Age-Grade Distortion in Brazil), UNICEF Brazil, Brasília, https://www.unicef.org/brazil/media/461/file/Panorama da distorcao idadeserie no Brasil.pdf (accessed on 7 April 2021). 
UNICEF (2018), Well-being and Multiple Deprivations in Childhood and Adolescence in Brazil, [20] UNICEF, Brasília, https://www.unicef.org/brazil/media/4541/file/Well-being-and-multipledeprivations-in-childhood-and-adolescence-in-brazil.pdf.pdf (accessed on 1 March 2021).

UNICEF (2017), Busca Ativa Escolar: Entenda a Metodologia Social e a Ferramenta [Active School Search: Understand the Social Methodology and the Technological Toolecnológica], UNICEF Brazil, Brasília, https://buscaativaescolar.org.br/downloads/guias-e-manuais/guia-metodologia-social-e-aferramenta-tecnologica.pdf (accessed on 23 February 2021).

Valenté, J. and M. de Almeida (2020), Brazilian Technology Policies in Education: History and Lessons Learned, https://eric.ed.gov/?id=EJ1261764.

Vaz Mondo, B. (2019), Proinfância ou Problema na Infância? Os desafios na construção de creches escolas em municípios brasileiros [Proinfância or Problem Childhood? Challenges in the construction of daycare centers in Brazilian municipalities], Transparência Brasil, São Paulo, https://www.transparencia.org.br/downloads/publicacoes/Obra\%20Transparente\%200706. pdf (accessed on 12 March 2021).

World Bank (2020), Support to Upper Secondary Reform Operation, Projects and Operations.

World Bank (2017), A Fair Adjustment: Efficiency and Equity of Public Spending in Brazil, World Bank, Washington D.C., http://documents1.worldbank.org/curated/en/643471520429223428/pdf/Volume-1Overview.pdf (accessed on 26 February 2021).

Zatti, A. and M. Minhoto (2019), "Evaluation Policy of the Teaching Performance in the Brazilian State Education Networks", Educação e Pesquisa, Vol. 45, http://dx.doi.org/10.1590/s1678-4634201945188993. 


\section{NOTES}

On 25 May 2018, the OECD Council invited Colombia to become a Member. While Colombia is included in the OECD averages reported in this publication for data from Education at a Glance, the Programme for International Student Assessment and the Teaching and Learning International Survey, at the time of preparation of these OECD datasets, Colombia was in the process of completing its domestic procedures for ratification and the deposit of Colombia's instrument of accession to the OECD Convention was pending.

PISA 2018 defines resilient students as those who are socio-economically disadvantaged, or from an immigrant background, and who score amongst the highest performers in PISA in their own country/economy. For more information, see Volume II of PISA 2018 (listed in the References section of this document).

1. The reference year for educational attainment data, NEETs data and employment data for Brazil, quoted throughout this report, is 2018. Please see OECD (2020[4]), Education at a Glance 2020: OECD Indicators, OECD Publishing, Paris, https://doi.org/10.1787/69096873-en.

2. For the rest of this profile, the use of the word "states" includes Brazil's 26 administrative states and the Federal District.

3. In Brazil, the different levels that compose primary education are referenced as "Years" (i.e. in Year 1 of primary education, students are around age 6) while the term, "Grade," is used for upper secondary education (i.e. in Grade 1 of upper secondary education, students are around age 15).

4. Data refer to final funds (after transfers between public and private sectors). The data refer exclusively to public expenditure in education, and do not capture private spending or public spending on tertiary student support schemes (as opposed to institutional subsidies).

This work is published under the responsibility of the Secretary-General of the OECD. The opinions expressed and arguments employed herein do not necessarily reflect the official views of OECD member countries.

This work and any map included herein are without prejudice to the status of or sovereignty over any territory, to the delimitation of international frontiers and boundaries and to the name of any territory, city or area.

The statistical data for Israel are supplied by and under the responsibility of the relevant Israeli authorities. The use of such data by the OECD is without prejudice to the status of the Golan Heights, East Jerusalem and Israeli settlements in the West Bank under the terms of international law.

Photo credits: Cover (C) Shutterstock/Sasha Chebotarev

(C) OECD 2021

The use of this work, whether digital or print, is governed by the Terms and Conditions to be found at: http://www.oecd.org/termsandconditions. 
This document has also been published as:

OECD (2021), Education Policy Outlook: Brazil - With a Focus on National and Subnational Policies, available at:

https://www.oecd.org/education/policy-outlook/country-profile-Brazil-2021-EN.pdf.
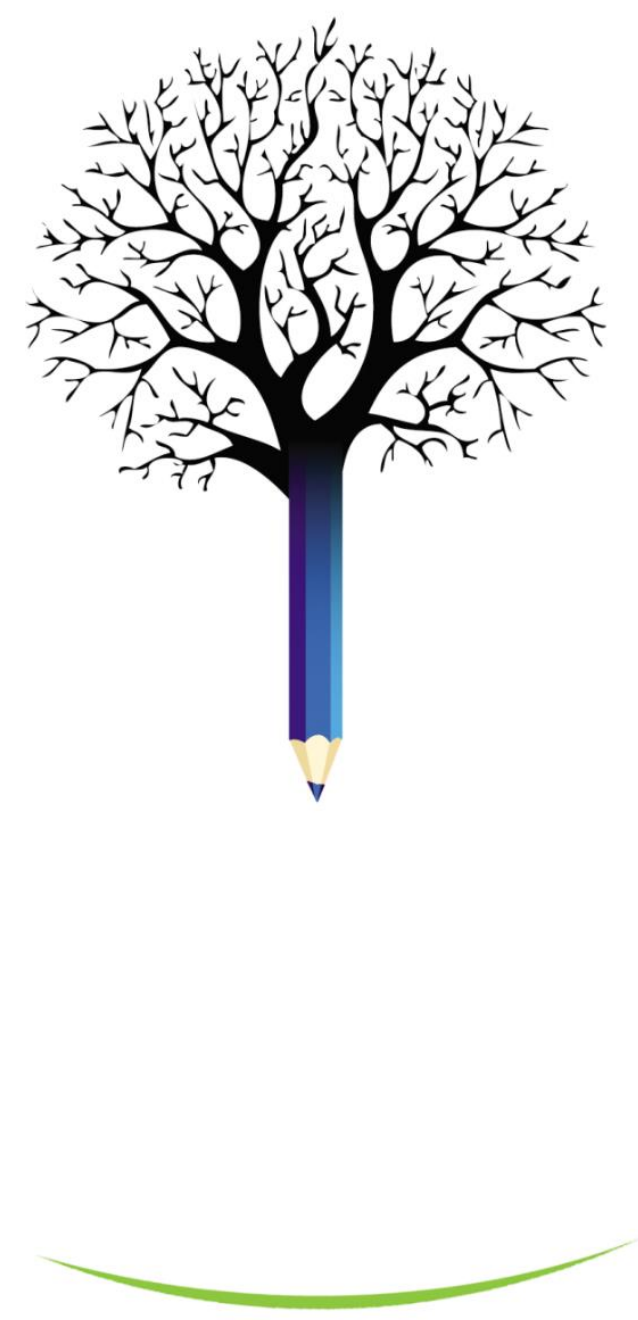